OPEN ACCESS

Edited by:

Nathalie Connil,

Université de Rouen, France

Reviewed by:

Dirk Benndorf,

Otto von Guericke University

Magdeburg, Germany

Guilherme Lanzi Sassaki,

Federal University of Paraná, Brazil

${ }^{*}$ Correspondence:

Maria Grimm

maria.grimm@uni-greifswald.de

Specialty section:

This article was submitted to Systems Microbiology,

a section of the journal

Frontiers in Microbiology

Received: 30 October 2020

Accepted: 10 March 2021

Published: 30 March 2021

Citation:

Grimm M, Grube M,

Schiefelbein U, Zühlke D, Bernhardt J and Riedel K (2021) The Lichens'

Microbiota, Still a Mystery?

Front. Microbiol. 12:623839.

doi: 10.3389/fmicb.2021.623839

\section{The Lichens' Microbiota, Still a Mystery?}

\author{
Maria Grimm $^{1 *}$, Martin Grube ${ }^{2}$, Ulf Schiefelbein ${ }^{3}$, Daniela Zühlke ${ }^{1}$, Jörg Bernhardt ${ }^{1}$ and \\ Katharina Riedel ${ }^{1}$
}

${ }^{1}$ Institute of Microbiology, University Greifswald, Greifswald, Germany, ${ }^{2}$ Institute of Plant Sciences, Karl-Franzens-University Graz, Graz, Austria, ${ }^{3}$ Botanical Garden, University of Rostock, Rostock, Germany

Lichens represent self-supporting symbioses, which occur in a wide range of terrestrial habitats and which contribute significantly to mineral cycling and energy flow at a global scale. Lichens usually grow much slower than higher plants. Nevertheless, lichens can contribute substantially to biomass production. This review focuses on the lichen symbiosis in general and especially on the model species Lobaria pulmonaria L. Hoffm., which is a large foliose lichen that occurs worldwide on tree trunks in undisturbed forests with long ecological continuity. In comparison to many other lichens, $L$. pulmonaria is less tolerant to desiccation and highly sensitive to air pollution. The namegiving mycobiont (belonging to the Ascomycota), provides a protective layer covering a layer of the green-algal photobiont (Dictyochloropsis reticulata) and interspersed cyanobacterial cell clusters (Nostoc spec.). Recently performed metaproteome analyses confirm the partition of functions in lichen partnerships. The ample functional diversity of the mycobiont contrasts the predominant function of the photobiont in production (and secretion) of energy-rich carbohydrates, and the cyanobiont's contribution by nitrogen fixation. In addition, high throughput and state-of-the-art metagenomics and community fingerprinting, metatranscriptomics, and MS-based metaproteomics identify the bacterial community present on $L$. pulmonaria as a surprisingly abundant and structurally integrated element of the lichen symbiosis. Comparative metaproteome analyses of lichens from different sampling sites suggest the presence of a relatively stable core microbiome and a sampling site-specific portion of the microbiome. Moreover, these studies indicate how the microbiota may contribute to the symbiotic system, to improve its health, growth and fitness.

Keywords: lichens, symbiosis, microbiome, lichen-associated bacteria, Lobaria pulmonaria, omics

\section{LICHENS: A FASCINATING SYMBIOSIS}

\section{Introduction}

Evolution is replenished with examples of symbiotic life forms, which often include great examples of emergent metabolic solutions and joint morphologies. Being terrestrial symbioses and widespread in natural habitats, lichens are eye-catching examples that developed characteristic growth styles of their joined symbionts at least 415 million years ago (Honegger et al., 2013). According to the classic definition, lichens are a mutualistic relationship of one exhabitant heterotrophic mycobiont (i.e., a fungus, in most cases an ascomycete) and an autotrophic 
photobiont. Because the fungal partner determines the morphology of lichens, classification is integrated in the system of fungi. Accordingly, lichens may also be understood as fungi forming self-sustained life-forms with algae. The large majority of the approximately 20.000 described lichen species are formed with a green alga as photobiont, whereas only $10 \%$ of lichens represent symbiotic associations with cyanobacteria. Two to four percent of lichenized fungi may associate with both types of phototrophs (e.g., Figure 1; Hawksworth et al., 1995; Honegger, 1996). The latter are commonly shared in a single fungal individual, where green algae dominate and auxiliary cyanobacteria colonize specialized gall-like compartments, called cephalodia (Büdel and Scheidegger, 1996). A few species may even develop differently shaped morphologies (photosymbiodemes) with either of the photobiont types (Nash, 2008), which allow them to establish in different environmental situations (Honegger, 1996; Stenroos et al., 2003).

\section{Where Do Lichens Occur?}

Lichens can grow on a broad range of substrates, yet, they are most common on bare rocks, on the bark of trees, or on compacted soil. Their habitats can be much more hostile than those favorable for higher plants (Kershaw, 1985; Walser, 2004). Despite being less productive, lichens can occur in rocky deserts or even at altitudes of up to $7400 \mathrm{~m}$. Lichens can also form a major component of cool and humid habitats (e.g., Arctic tundra, boreal forest floors, lava fields, antarctic habitats, or rock surfaces in high altitudes or at the coast with tidal inundation). In certain ecosystems (e.g., tropical montane forests or temperate wet forests), epiphytic lichen biomass may exceed several hundred kilograms per hectare (Kershaw, 1985; Boucher and Stone, 1992; Coxson and Nadkarni, 1995). Yet, despite the outstanding tolerance of many species for desiccation, radiation, and extremes of temperatures in hostile environments, lichens are known as bioindicators of specific ecological situations. Apparently, lichens are very sensitive to ecological conditions when they are metabolically active, but they may tolerate extreme conditions when dry and metabolically inactive.

\section{Special Peculiarities of the Lichen Symbiosis Morphology}

Lichens develop a wide range of morphological shapes and growth styles including brushy, crust-like, or leaf-like forms, to name just the most important ones. Crustose thalli attach directly to the substrate with their entire lower surface, yet many species can also develop within the substrate (e.g., in sandstone,

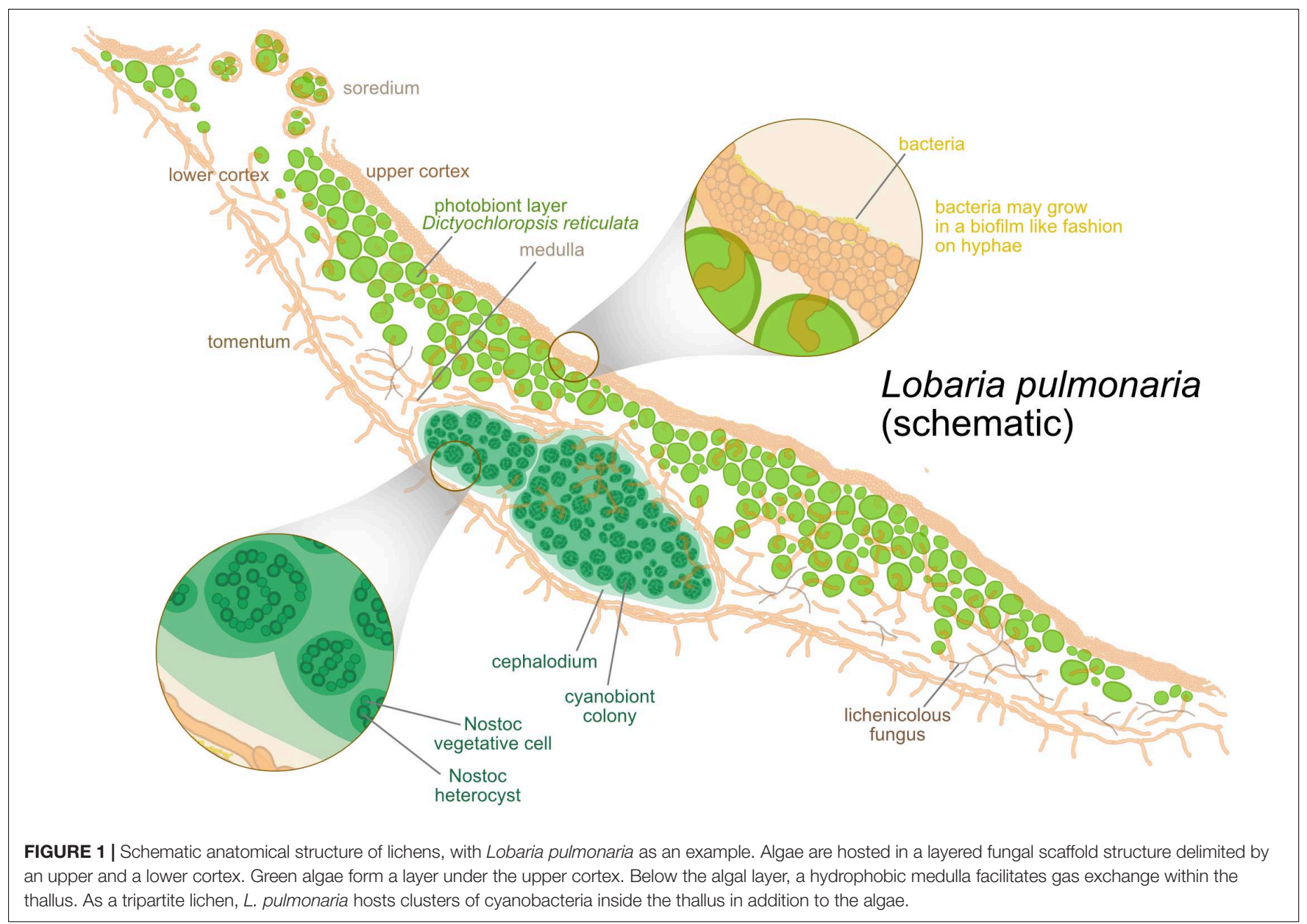


calcareous rocks, or bark). Surface-detached thalli often develop specific holdfast structures. In contrast to crustose forms, lichens with leaf-like growth styles are often devoid of degrading algal cell wall remnants in their upper fungal cortex layers. The apparent lack of expressing algal cell wall digestive functions in these species possibly gives their thalli structures higher hygroscopic flexibility and structural stability. For a long time, lichen systematists classified lichens exclusively according to their thallus morphologies or by details of reproductive structures, until molecular data revealed the phylogenetic relationships of those forms in better detail. Since then, molecular studies uncovered multiple cases of convergent evolution of similar growth styles, and the repeated evolution of surface-detached forms from crustose ancestors (Grube and Hawksworth, 2007).

The proper development of the vegetative lichen thallus with specific algal strains is also generally necessary but not always sufficient for sexual reproduction by fruitbodies of the mycobiont partner and/or for production of asexual/mitotic structures for joint propagation of both symbionts.

Most of the lichen thalli are rather brittle when dry, but rather flexible when wet. Some of those containing cyanobacteria may then have a rather gelatinous consistency as well (Büdel and Scheidegger, 1996).

The formation of tight, yet swellable fungal layers to wrap algal colonies, is apparently one of the key evolutionary innovations enabling lichen thallus evolution. The processes leading to gluing fungal hyphae together by their outer cell walls might be related to those involved in the formation of fruit body structures in ascomycetes. The interaction of the fungi with appropriate photobionts is required for the production of the characteristic thallus morphologies, but also for production of specialized metabolites, which accumulate - often at substantial amounts - as crystallized lichen compounds in the intercellular spaces of the thalli.

\section{What Holds the Lichen Together?}

Hydrophilic, extracellular substances (EPS; Figure 1; Spribille et al., 2020) achieve the gluing together of short, branched and anastomosing fungal hyphae. In many lichens, the protecting conglutinated fungal layer not only contains mycobiont hyphae, but also bacteria and basidiomycete yeasts. Due to its welldeveloped EPS and multiorganismal composition, this layer can thus be considered as a complex biofilm or as an extracellular interaction matrix (EIM; Spribille, 2018; Tuovinen et al., 2019). The EIM not only functions as a sort of exoskeleton for stabilization but also as a receptacle for mineral nutrients, a development zone for secondary metabolites and as medium of intercell recognition and signaling. As far as is known, the EIM of lichens contains different polysaccharides, which typically consist of D-glucose, D-galactose and D-mannose. The different polysaccharides, such as $\beta$ - and $\alpha$-glucans, $\alpha$-mannans or heteroglycans, found in lichen mycobionts are discussed in several reviews (e.g., Olafsdottir and Ingólfsdottir, 2001; Spribille et al., 2020).

The Basidiomycete genus Tremella produces glucuronoxylomannans as exopolysaccharide capsule material (GXM; Gorin and Barreto-Bergter, 1983;
De Baets and Vandamme, 2001; Martinez and Casadevall, 2015). No GXM is currently known from lichens, but Tremella yeasts are known from several lichens such as Letharia vulpina (Tuovinen et al., 2019). Therefore, Spribille et al. (2020) assume that GXM occurs also in lichens. This would agree with observations of Grube and De Los Rios (2001) who observed acidic polysaccharides on the outer cell walls of the lichen-associated Tremella relative Biatoropsis usnearum. Beside polysaccharides found in the EIM and secreted by fungal partners, additional ones are isolated from lichen algal photobionts, like amylose, $\beta$-xylan (Cordeiro et al., 2003), $\beta-(1 \rightarrow 5)$-galactofuranan (Cordeiro et al., 2005, 2008), rhamnogalactofuranan (Cordeiro et al., 2013), mannogalactan (Cordeiro et al., 2010), cellulose or 4-linked mannan (Carbonero et al., 2005; Centeno et al., 2016). Additionally, some cyanobacterial EPS are known, such as $\beta$-(1 $\rightarrow 4)$-xylan and a complex polysaccharide formed of $\beta$-linked L-arabinose and D-xylose (Ruthes et al., 2010).

The role of lichen-associated bacteria in EIMs will be discussed in sections "Uptake and supply of nutrients, essential compounds and trace elements" and "Microbiome Acquisition and Shaping."

\section{Poikilohydry: Life With Fluctuating Water Supply}

Lichens are poikilohydric organisms meaning that they lack the ability to maintain and/or actively regulate their water content. Rather, their water status varies passively with the surrounding environmental conditions. In this regard, lichens differ from higher plants, where stomata and the cuticula help to manage the water balance. Therefore, lichens do not have a clearcut separation between exo- and endosphere. As poikilohydric organisms, many lichens evolved extraordinary tolerance to desiccation. This includes antioxidant and photoprotective mechanisms (Kranner et al., 2005, 2008), and strategies enabling the lichen to cope with mechanical stress under changing hydration conditions. In dry conditions, the fungal layer consists of a dense EPS matrix and compressed hyphae. During lichen hydrating, the extracellular matrix expands by multiple times of its desiccated volume (Spribille et al., 2020). A more or less coherent layer that can flexibly respond to shrinking and swelling of the algal cells under variable conditions of hydration represents a main principle of the vegetative mycelium. The adaptation of some lichens to habitats with different water regimes also includes the choice of the photobiont. Green algae in lichens can activate their photosynthesis in a humid/moist environment whereas cyanobacteria in lichens usually require liquid water (Richardson, 2002). This explains why cyanolichens are more commonly found under conditions characterized by run-off water. Generally, the light and desiccation tolerance is facilitated by symbiotic interaction, thus ameliorating the stress faced by separated partners (Walser, 2004; Kranner et al., 2005; Jüriado and Liira, 2009; see also section "What Holds the Lichen Together?").

\section{Reproduction}

Sexual reproduction of the algal partner is generally suppressed, but the fungal partner sexually reproduces commonly by production of meiospores in fruit-bodies. Fruit-bodies are usually perennial and can produce spores for many years under suitable 
circumstances, unlike those of many non-lichenized ascomycetes. Asexual, mitotic reproduction of the fungal partner is also known (e.g., thallospores, conidia). However, the fungal spores need to re-establish the symbiosis with a specific photobiont species, and despite the partners having the potential to grow autonomously (as they can be cultivated separately and are found by environmental sequencing), only the encounter of suitable photobiont initiates the ontogenetic processes to produce the characteristic thallus morphology. Therefore, lichens evolved also very diverse forms of asexual symbiotic propagules apart from the dispersal of fungal propagules alone (Figure 1). These structures range from dust-like or grainy microscopic particles containing few algal-encaging fungal hyphae (soredia) to more complex, stratified structures of different shapes and sizes (blastidia, isidia, schizidia, phyllidia, etc.) or small thallus fragments (folioles, squamules, etc.) that easily detach from the parental lichen thallus (Bowler and Rundel, 1975; Scheidegger, 1995).

\section{Lichen Tolerance to Toxic Compounds}

A remarkable feature of lichens (and many other macroscopic fungi) is that they are valuable and sensitive bioindicators of environmental and industrial pollution. Most lichens are sensitive to sulfur dioxide, which disrupts photosynthesis. Some lichens, however, have the ability to reduce the uptake of acidic precipitation containing sulfur dioxide. Hauck et al. (2008) pointed out that surface hydrophobicity is the main factor controlling the tolerance of these lichens for sulfur dioxide. Hydrophobicity could also explain that sulfur dioxide tolerant lichen species show a general toxin tolerance. As lichens also take up and tolerate metals in the thallus, they are used for environmental monitoring of industrial pollution (Garty, 2001). The production of metal oxalates (e.g., hydrated copper oxalate, manganese oxalate or lead oxalate) is a common adaptive biological mechanism for metal detoxification in lichens (reviewed by Purvis, 2014). Superficial oxalates on the thallus surface may help deflect the amount of light reaching the lichen photobiont and therefore help lichens to survive in extreme environments. An additional detoxification response to heavy metals is found in Lecanora polytropa. Phytochelatin (cysteinerich peptides derived from glutathione) is produced to chelate these metals intracellularly (reviewed by Purvis, 2014).

\section{Symbiotic Partnership \\ Mycobiont: Home Sweet Home}

The lichen-forming fungus develops the characteristic morphology of the lichen. It exposes the photobiont to controlled levels of sunlight during physiologically active stages, because a too strong light intensity can damage the photobiont (Figure 1; Larson, 1987).

A highly hydrophobic cell wall surface layer of mycobiont origin can be formed at the contact of the growing hyphae with a photobiont cell. This layer spreads over the wall surface of the entire algal cell, which seals the apoplastic space and channels the metabolic flux among symbiotic partners. Proteins, lipids and fungal derived phenolic secondary compounds form this hydrophobic coat. These secondary metabolites crystallize on and within the cell wall surface layer (Honegger, 1984, 1991; Scherrer et al., 2000).

The mycobiont is able to shift the position of the algal cells over short distances to secure adequate illumination and most efficient photosynthesis (Honegger, 1987, 1990). The hydration state of the cortical layer influences the light absorption and transmission. Additionally, the thickness of the cortical layer or the presence of insoluble mineral complexes, such as oxalates of calcium, copper, magnesium or manganese, and fungalderived crystalline secondary compounds may affect the amount and spectral composition of incoming light (Honegger, 1991). Furthermore, the cortical layer has to facilitate the gas exchange of its algal photobiont (Honegger, 1990), which benefits from the position of the photobiont cells at the periphery of the gasfilled thalline interior underneath the fungal cortical layer. The cortex allows $\mathrm{CO}_{2}$ diffusion when the thalline water content is moderate, while water-supersaturated conditions may limit net photosynthesis rates significantly. As an adaptation to adequate level of $\mathrm{CO}_{2}$ absorption, a distinct proportion of the thalline volume [e.g., 30-50\% in Parmelia sulcata (Fiechter, 1990)] acts as gas-filled intercellular space in the medullary and algal layers where mycobiont-derived respiratory $\mathrm{CO}_{2}$ can be stored (Honegger, 1991).

High light intensity can damage the photobiont (e.g., Demmig-Adams et al., 1990; Gauslaa and Solhaug, 1996, 1999, 2000). Depending on the long-term level of solar radiation, some lichenized fungi also produce melanic compounds in the outer layer of the upper cortex as a sunscreen. The melanic compounds reduce UV-B and UV-A wavelengths, but also visible wavelengths, reaching the photobiont layer. The melanisation leads to a browning of the cortex. This browning of the cortex is a physiologically active process, which occurs only in hydrated lichen thalli (Gauslaa and Solhaug, 2000, 2001; Solhaug et al., 2003; Antoine and McCune, 2004; Gauslaa and McEvoy, 2005; McEvoy et al., 2007; Nybakken et al., 2007; Matee et al., 2016; Mafole et al., 2017). As a side effect, melanins increase the absorbance of solar energy for the whole thallus resulting in a temperature increase of up to $3^{\circ} \mathrm{C}$, which could suggest quicker water loss than in other species, which instead use crystallized secondary metabolites (e.g., atranorin) as light shields. Secondary metabolites appear as effective as melanin in reducing the transmission of photosynthetic active radiation, but reflect rather than absorb this radiation. Thus, these compounds have less effect on the heat balance of lichens (McEvoy et al., 2007; Solhaug et al., 2010; Mafole et al., 2017). Beside the production of melanic compounds or secondary metabolites, curling of the thalli during drying represents an additional strategy against serious photodamaging thalli of L. pulmonaria during high light exposure (Barták et al., 2006).

\section{Photobiont: The Breadwinner}

The photobiont produces and secretes mobile energy-rich carbohydrates, which are provided to the fungal partner as sugar alcohols, such as polyols including ribitol, erythritol or sorbitol (Richardson et al., 1968; Hill, 1972; Brown and Hellebust, 1978; Smith and Douglas, 1987; Eisenreich et al., 2011; Eymann et al., 2017). The photobiont's cell walls are permeable to 
carbohydrates in the lichenized state. Therefore, ribitol reaches the lichen fungus via diffusion (Richardson et al., 1968; Hill, 1976). The photosynthate release is probably stimulated by the synthesis and metabolism of taurine (Wang and Douglas, 1997). Taurine catabolism dioxygenase, which is an indicator for sulfonate utilization and metabolism of taurine, is identified in the proteome of the mycobiont of L. pulmonaria (Eymann et al., 2017). For storage, the mycobiont partly converts the carbohydrates provided by the photobiont into mannitol via the pentose phosphate pathway (Smith, 1980; Lines et al., 1989; Eisenreich et al., 2011). Polyols cannot be regarded as safe storage products because they can be washed out of the thallus during rewetting after drought stress (MacFarlane and Kershaw, 1985; Dudley and Lechowicz, 1987). Polyols more likely protect enzyme systems during stress events and act as osmoregulators during the wetting and drying cycles. Additionally, they can be substituted for water and stabilize proteins and membranes under dry conditions (Bewley and Krochko, 1982; Farrar, 1988; Jennings and Lysek, 1996). This raises the interesting hypothesis that the green algae originally synthesize the sugar alcohols only as compatible solutes mainly just to keep water in the cells and to protect their proteins under dry stress conditions. Rapid rewetting, e.g., by rain, could force the green algae to export polyols very rapidly to prevent uncontrolled water influx and cell damage. Involuntarily released sugar alcohols could thus possibly played a role in early stages of lichen evolution.

When the lichen thallus is drying the water from the apoplastic space between the cell walls of the symbiotic partners is lost at first. Afterward, cellular water is partially lost, leading to drastic but reversible cell shrinkage. The mycobiont and photobiont cells are able to tolerate dramatic fluctuations in cellular water contents between saturation $(>150 \%$ water content in relation to dry weight) and desiccation $(<20 \%$ water content in relation to dry weight). Soluble compounds are passively released into the apoplastic space due to reversible leaching from the cell during extreme drought. Lichen photobionts reversibly inactivate their photosystem II during desiccation. Water flows passively back and forth within the apoplastic space during the regularly occurring de- and rehydration of the thallus. Thereby, not only dissolved mineral nutrients, but also other passively and actively released metabolites from the symbiotic partners are translocated (MacFarlane and Kershaw, 1985; Brown et al., 1987; Dudley and Lechowicz, 1987; Honegger, 1991, 1997; Scheidegger, 1994; Heber et al., 2010).

Eymann et al. (2017) assign beta-catenin to the proteome of the algal photobiont of L. pulmonaria. It is important for the signaling during cell-cell adhesion of unicellular organisms (Abedin and King, 2010), in the case of lichens between cells of the mycobiont and photobiont or among the photobiont cells and allows a rapid exchange of signals and substrates.

\section{Cyanobiont: Grabbing Nitrogen}

In tripartite lichens, the cyanobiont is predominantly responsible for nitrogen fixation (Millbank and Kershaw, 1970). This is supported by the identification of glutamate synthase and molybdenum nitrogenase in the proteome of the cyanobiont of L. pulmonaria (Eymann et al., 2017). In other lichens, such as Peltigera aphthosa, alternative nitrogenases, which use vanadium or iron instead of molybdenum at the active site, might also play an important role in biological nitrogen fixation lichens (Darnajoux et al., 2017). Because oxygen is inhibiting denitrogenase, the fungal partner creates microaerobic conditions and accumulates the cyanobiont cells in gall-like structures, also known as cephalodia (Jordan, 1970; Hawksworth and Hill, 1984; Jahns, 1988; Honegger, 1993; Büdel and Scheidegger, 1996; Cornejo and Scheidegger, 2013). Nitrogen fixation of the cyanobionts of lichens is substantial for nitrogen cycling in nutrient-poor environments where nitrogen leaks from growing and degrading lichens (Nash, 1996). In tripartite lichens, the cyanobacterial heterocyst frequency is increased. In bipartite lichens, the heterocyst frequency varies between $2 \%$ and $8 \%$, whereas in tripartite lichens, it varies between $10 \%$ and $55 \%$. Nevertheless, the relative number of cyanobacteria is kept lower than that of the algal photobiont. Thus, the lichen fitness increases through specialization of the cyanobiont on nitrogen fixation (Hyvärinen et al., 2002).

Although labor partition favors the role of nitrogen fixation in cephalodiate cyanobionts, the cyanobiont is also partly responsible for carbon fixation and thus, involved in photosynthesis. Cyanobacteria as well as red algae have a lightharvesting complex, which is different to that of green algae, the phycobilisome. This complex is built up of phycobilins, like phycoerythrin and phycocyanin. The phycobilisome absorbs light between $450 \mathrm{~nm}$ and $650 \mathrm{~nm}$ and sometimes beyond $700 \mathrm{~nm}$. Chlorophyll a and b absorb light between 400 and 480 (blue light) and between 550 and 700 (yellow to red light). Therefore, green light is rarely absorbed by the green algal photobiont, whereby tripartite lichens and chlorolichens appear greenish (Kadereit et al., 2014; Adir et al., 2019). The existence of phycobilisome proteins is reported in the proteome of the cyanobiont of L. pulmonaria (Grube and Berg, 2009; Eymann et al., 2017).

\section{Mycobiome: The Recycler, Probably?}

The longevity and slow growth of lichen structures may also foster the colonization of lichens by more or less specific additional microorganisms. Lichenicolous (= lichen colonizing) fungi (Figure 1) were actually recognized even before the symbiotic nature of lichens was discovered in the second half of the 19th century. About 1800 lichenicolous fungi are known today and most of these are characterized by their morphological structures $^{1}$ (Lawrey and Diederich, 2003; Diederich et al., 2018). Each lichen can harbor a wide range of additional fungal components, which constitute an associated mycobiome (Fernandéz-Mendoza et al., 2017; Muggia and Grube, 2018). The majority of the lichenicolous fungi only cause local infections in the host thallus or are more or less commensalic. The commensalic behavior usually correlates with a preference for the algal photobiont of the host lichen. Recent evidence suggests that commensalism also applies to yeasts resident in fungal layers of the lichen. Spribille et al. (2016) assumed that commensalic basidiomycete yeasts residing in the fungal upper

\footnotetext{
${ }^{1}$ www.lichenicolous.net
} 
cortex maintain close associations with specific lichen species over large spatial distances. This view was questioned by recent evidence of low host specificity of yeast stages compared to the known mycelial lichenicolous fungi. According to Mark et al. (2020), various epiphytic lichen species growing on the same tree trunk consistently harbor specific Trebouxia lineages as photobionts, while genotypes of the cystobasidiomycetous yeasts were irregularly distributed among the species.

Lichenicolous fungi contact the cells of their hosts using specific structures. De Los Rios and Grube (2000) described infectious hyphal structures, including simple or complex haustoria with projections into the host hyphae. Other species were found to use haustoria to penetrate the algal photobiont of their hosts (Zwackhiomyces; Grube and Hafellner, 1990). Furthermore, some lichen-associated fungi have necrotic to saprobic life styles, preferring decaying parts of lichens (Aptroot and Alstrup, 1999). Other lichenicolous fungi can cause hypertrophic deformations (galls) in lichen thalli, which usually contain hyphae of both fungal species. These galls also provide a microhabitat for additional fungi, including the yeast genus Cyphobasidium (Millanes et al., 2016).

Only a small fraction of lichenicolous species actually cause dramatic damage to their hosts and may rapidly erase lichen coverage of substrates (including the facultative lichen pathogen Athelia arachnoidea).

Lichenicolous fungi, which use structures of the host to establish their own lichenized thalli are called lichenicolous lichens (Poelt, 1990). Their parasitic thalli develop on the surface or as internal structures of the host (Grube, 2018), and they often also take up the algae of the hosts. Because the lichenicolous lichens can also be infected by lichenicolous fungi, lichens also provide interesting examples of hyperparasitism. For example, the lichenicolous lichen Rhizocarpon diploschistidina parasitizes the lichen Diploschistes muscorum, which usually grows as a juvenile parasite of Cladonia species (Lumbsch et al., 2011).

\section{Microbiome: The New Teammate}

Lichen-associated bacteria were initially isolated in the first half of the 20th century (Cengia Sambo, 1926; Henckel and Yuzhakova, 1936; Honegger, 1990). These characterizations already indicated a possible role in nitrogen fixation for some of these lichenassociated bacteria. Evidence for the presence of bacteria (other than cyanobacteria) in lichens is provided by a series of studies that are based on morphological evidence using cultivable isolates of bacteria in lichens (e.g., Panosyan and Nikogosyan, 1966; Henkel and Plotnikova, 1973). In the early 1980s, Lenova and Blum (1983) estimated that millions of bacterial cells per gram could colonize a lichen thallus. More than 20 years later, diversity and specificity was studied in more detail by culture-independent sequencing approaches, and later by more sophisticated omics technologies, which demonstrated that lichens are furnished with a complex bacterial microbiome (Figure 1) (e.g., González et al., 2005; Cardinale et al., 2006; Liba et al., 2006; Grube et al., 2009; Selbmann et al., 2010; Bates et al., 2011; Hodkinson et al., 2012; Aschenbrenner et al., 2014). The lichen microbiome is identified as a surprisingly abundant and structurally integrated element of the classical lichen symbiosis (e.g., Gauslaa and
Solhaug, 1996, 1999; Aschenbrenner et al., 2016; Leiva et al., 2021). These studies reveal that lichen-associated bacterial communities are not merely a simple extension of the prokaryotic community of the lichen-surrounding environment. The lichen microbiome consists of two parts. The first part is a core microbial community. Therefore, the microbiome is stable to a certain extent. The second part of the microbiome is a specific microbial community, even in close spatial proximity or when lichens are reshaped by parasitic invasion of one lichen into the other (Wedin et al., 2016). Thus, the lichen species is probably the best predictor of its microbiome composition (Bates et al., 2011). These findings led to reconsideration of the lichen symbiosis including the microbiome as an additional component (Hawksworth and Grube, 2020).

\section{Lichen-Associated Viruses}

Reports of lichen-associated viruses are found in recent studies. In several lichens, single and double-stranded RNA viruses, similar to those of plants were found (Petrzik et al., 2014, 2016). Yet, lichen viruses are not only of apparent algal origin. Petrzik et al. (2019) detected novel dsRNA viruses in the lichens Chrysothrix chlorina (Chrysothrix chrysovirus 1; CcCV1) and Lepraria incana (Lepraria chrysovirus 1; LiCV1) and classified them to the genus Alphachrysovirus, with a relationship to chrysoviridae from filamentous ascomycetous fungi. However, the authors showed that CcCV1 was not found in the lichen mycobiont but in the accompanying endolichenic fungus Penicillium citreosulfuratum. Using dsRNAseq technology, Urayama et al. (2020) characterized the total dsRNA viral community of a lichen species (species name not indicated, but apparently belonging to the Cladonia pyxidata complex according to their Figure 1), and revealed that partitiviruses were dominant and active. Sequences found in this study were classified into two genera, which include both plant- and fungi-infecting partitiviruses. Apparently, each of the lichen partners may harbor several virus species independently and simultaneously because CaMV and the capsid protein gene of ApMV were detected in the photobiont of Xanthoria parietina and both, the plant cytorhabdovirus and the ApMV, were detected in U. chaetophora (Petrzik et al., 2014, 2015). Also, proteins assigned to rhabdoviruses and betaflexiviruses were found in the metaproteome of L. pulmonaria (Eymann et al., 2017), and Grube et al. (2015) found bacteriophage sequences in the metagenome of the same lichen. Presence of bacteriophages in lichens is confirmed by occurrences of bacteriophage proteins assigned to the families Myoviridae and Siphoviridae which infect Bacteria and Archaea (Eymann et al., 2017).

\section{THE PROKARYOTIC MICROBIOME OF LICHENS}

\section{Bacteria Living With Lichens}

More than 800 types of bacteria can contribute to the bacterial microbiome of a single lichen individual. In many so far studied lichens, Alphaproteobacteria form the largest and metabolically most active bacterial class 
(Cardinale et al., 2006, 2008; Grube and Berg, 2009; Grube et al., 2009, 2015; Bates et al., 2011; Schneider et al., 2011). Within the Alphaproteobacteria, the Rhizobiales make up the majority. In chlorolichens, Rhodospirillales are often codominant contrary to cyanolichens where Sphingomonadales normally co-dominate. However, Alphaproteobacteria are not always dominant. The rock-inhabiting lichen Ophioparma is dominated by Acidobacteria (Hodkinson et al., 2012), and marine lichens (e.g., Lichina pygmaea) differ by a dominance of Bacteroidetes beside Chloroflexi and Thermi (West et al., 2018). Due to their preference to form communities with fungi and in addition with Alphaproteobacteria on plant surfaces, it is not surprising to find also Paenibacillus and Burkholderia phylotypes within the microbial community of terrestrial lichens (Berg and Hallmann, 2006; Cardinale et al., 2006; Grube and Berg, 2009; Partida-Martinez et al., 2007). Other well-known bacterial lineages can be found in lichens such as Firmicutes, Bacteroidetes, Verrumicrobia, Acidobacteraceae, Acetobacteraceae, Brucellaceae or Chloroflexi (González et al., 2005; Grube et al., 2009; Bates et al., 2011; Schneider et al., 2011; Hodkinson et al., 2012; Garg et al., 2016).

So far, most microbiome studies focused on lichens belonging to Lecanoromycetes. One of them is the lung lichen L. pulmonaria L. Hoffm. (Figure 2) and is currently under intense investigation. One third of the overall bacteria in L. pulmonaria belong to the Rhizobiales (in particular to the families Methylobacteriaceae, Bradyrhizobiaceae, and Rhizobiaceae), which are well known partners in plantmicrobe interactions (Erlacher et al., 2015). Actinobacteria, Betaproteobacteria, Firmicutes or Deinococcus (Cardinale et al., 2006; Hodkinson and Lutzoni, 2009) and Archaea are complementing the L. pulmonaria microbiome (Schneider et al., 2011; Eymann et al., 2017). L. pulmonaria is an interesting model to investigate genotypic and phenotypic traits that enable the lichen to adapt to changing climate conditions. In the following paragraphs, we will present a more detailed look at L. pulmonaria and its microbiome together with the microbiome of other lichen species. Moreover, we will introduce important techniques for studying composition and function of lichen microbiomes.

\section{The Model Lichen L. pulmonaria}

Lobaria pulmonaria is a large foliose lichen (Figure 2A). Besides a myco- and a photobiont, L. pulmonaria contains a cyanobiont, a cyanobacterium belonging to the genus Nostoc. The green algal photobiont Dictyochloropsis reticulata dominates $90 \%$ of the subcortical layer of the thallus (Honegger, 1991; Myllys et al., 2007; Figure 2B).

Lobaria pulmonaria is distributed over an area in the Northern Hemisphere from the boreal to the meridional zone (Figure 3, GBIF.org 2019). In Eurasia as well as in Northern America, it has a Western and an Eastern subarea, excluding regions influenced by a strong and dry continental climate with precipitation less than (450)-500 mm. Furthermore, L. pulmonaria occurs in the montane belt of East Africa, on Madagascar, the Mascarene archipelago and in South Africa (Figure 3). Occurrences in Central America still merit further investigation and need to be validated. The geographic range reflects the ability of
L. pulmonaria to inhabit regions with different overall conditions. The mean annual temperature at the Northernmost locations in Scandinavia is about $1{ }^{\circ} \mathrm{C}$ and the mean annual precipitation about $500 \mathrm{~mm}$, on the Azores archipelago about $18^{\circ} \mathrm{C}$ and $1.500 \mathrm{~mm}$, respectively, and in Siberia at the Baikal lake $-0,9^{\circ} \mathrm{C}$ and about $500 \mathrm{~mm}$, respectively (Worldclim 2.0). Consequently, L. pulmonaria occurs in a wide spectrum of habitats mostly on tree trunks, e.g., Fagus sylvatica, Quercus robur or Acer platanoides (Hakulinen, 1964; Wirth, 1968; Hallingbäck and Martinsson, 1987; Rose, 1992; Wolseley and James, 2000; Kalwij et al., 2005; Jüriado and Liira, 2009; Smith et al., 2009; Wirth et al., 2013), but it can also colonize dwarf scrubs (e.g., Calluna), mossy rocks and soil (Ingólfsdóttir et al., 1998; Scheidegger and Goward, 2002; Grube et al., 2015). The current distribution of L. pulmonaria is the result of several factors. Air pollution by sulfur dioxide (e.g., Hawksworth and Rose, 1970; Hawksworth et al., 1973; Hallingback and Olsson, 1987; Farmer et al., 1991), and later, by nitrogen containing air pollutants (e.g., Hauck and Wirth, 2010) led to extinction or a reduced frequency in many regions of the original distribution area. The forestry practices strongly influenced L. pulmonaria in different respects for a long time. Clear cutting and afforestation with trees not suitable to the location (e.g., spruce, pine) led directly to the loss of habitats, other forestry measures to negative changes of the habitat conditions (e.g., Edman et al., 2008; Jüriado et al., 2011; Wirth et al., 2011; Schiefelbein and Thell, 2018). In conclusion, L. pulmonaria occurs mostly in undisturbed natural forests, with long ecological continuity due to a stable environment in terms of light, moisture and temperature, which are little influenced by air pollution, agriculture and forestry practices.

Under suitable conditions, L. pulmonaria may have a long life (acc. to estimates up to 200 years) (Scheidegger et al., 1998) and is described as a 'patchtracking' organism (Snäll et al., 2003), colonizing tree boles, where it may persist until the tree dies or microclimatic conditions change. During the life cycle of L. pulmonaria, estimated to an average of 35 years, the dispersal via vegetative diaspores (soredia, isidioid soredia) or thallus fragments predominates (Scheidegger et al., 1998; Scheidegger and Goward, 2002). Molecular and empirical studies show that L. pulmonaria can efficiently propagate by their vegetative propagules up to $75 \mathrm{~m}$ (Walser et al., 2001; Öckinger et al., 2005; Werth et al., 2006), but the majority of L. pulmonaria vegetative propagules are detected at a very short spatial scale, i.e., < $40 \mathrm{~m}$ (Werth et al., 2006). Under proper conditions (which usually agrees with larger thallus sizes), fruitbodies and ascospores develop (Scheidegger and Goward, 2002; Martínez et al., 2012; Wirth et al., 2013) and facilitate the long-distance dispersal of the mycobiont (Werth et al., 2006). With up to $5 \mathrm{~mm}$ annual tip growth, L. pulmonaria is one of the fastest growing lichens in Europe (Phillips, 1969). Microsatellite analysis by Werth and Scheidegger (2012) reveal dispersal via symbiotic propagules as the key factor shaping the genetic structure of this species. The highest growth rates and shortest generation times, with reproductive maturity are achieved within around five to ten years, as Eaton and Ellis (2014) observe in an oceanic hazelwood in Western Scotland. Thus, in oceanic environments, 
A

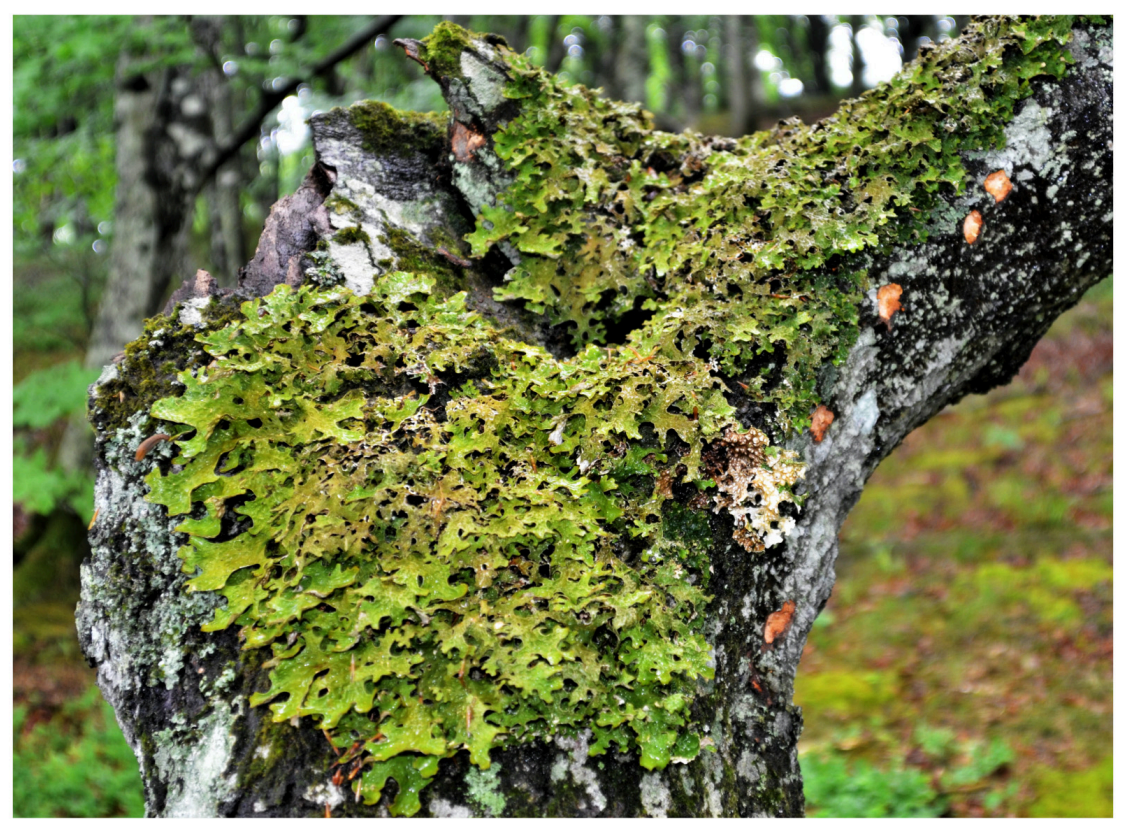

B

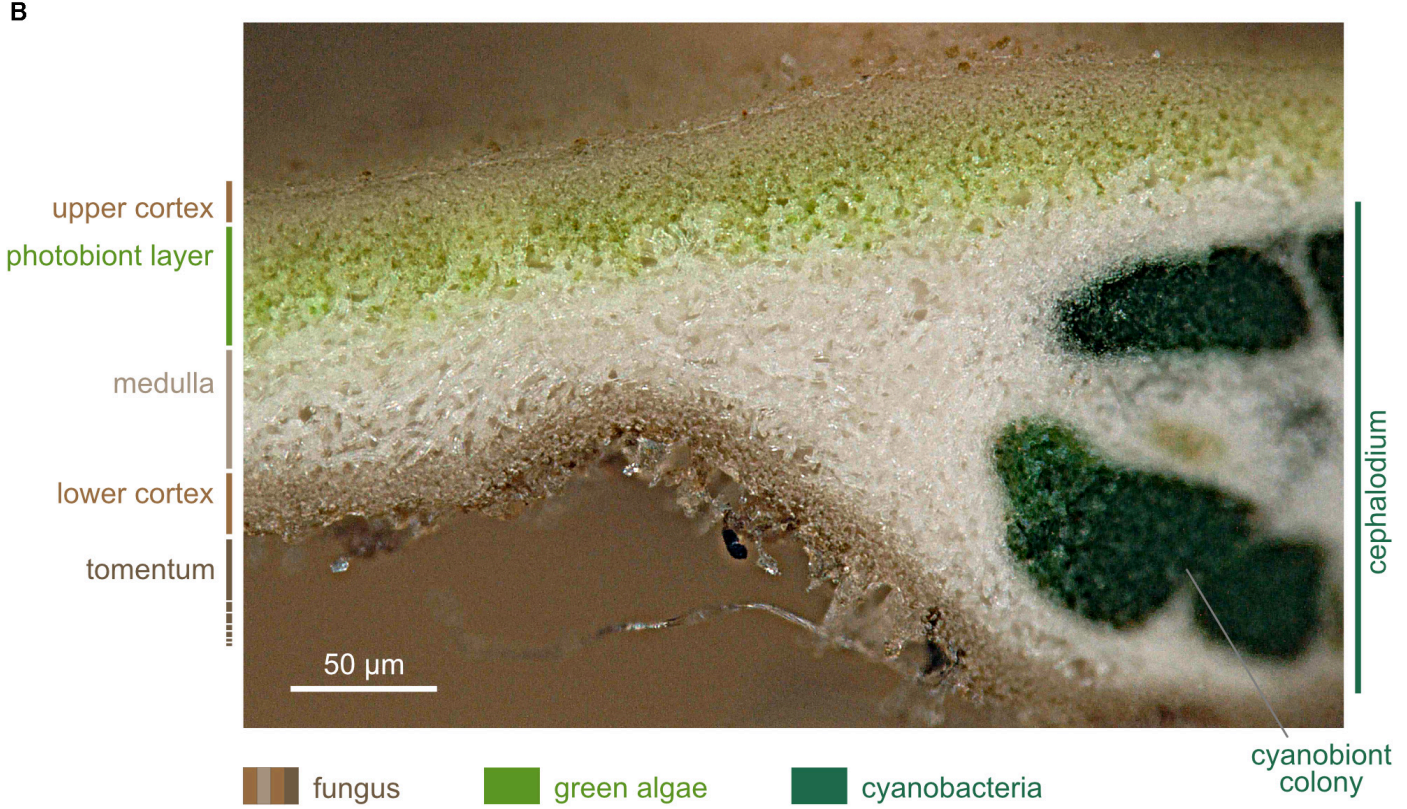

FIGURE 2 | Lobaria pulmonaria. (A) Specimen growing on Fagus sylvatica (photographed in May 2016 near Viborg, Denmark); (B) Microscopic cross section. The upper cortex forms the habitat of the microbiome. Image produced with dry, sectioned material using a Keyence Digital VHX-5000 microscope with automated image stacking.

e.g., along the west coast of Scotland (Seaward, 1998; Eaton and Ellis, 2014), L. pulmonaria is very common. The difference in abundance between oceanic and more continental environments possibly reflects an interaction between the macroclimate and an organisms' microhabitat specificity (Lisewski and Ellis, 2010), such that a species may become increasingly restricted to a limited suite of buffered microclimatic niches under sub-optimal macroclimatic conditions (Doering and Coxson, 2010), and therefore rarer.
Because of its specific features and threats, L. pulmonaria is extinct or at risk in many regions of its distribution area (e.g., Türk and Hafellner, 1999; Scheidegger and Clerc, 2002; Bardunov and Novikov, 2008; Randlane et al., 2008; Farkas and Lõkös, 2009; Aptroot et al., 2012; Wirth et al., 2011).

This lichen species is used as a model lichen for studies on the lichen microbiome mainly due to its relatively fast growth and its ecological significance. 


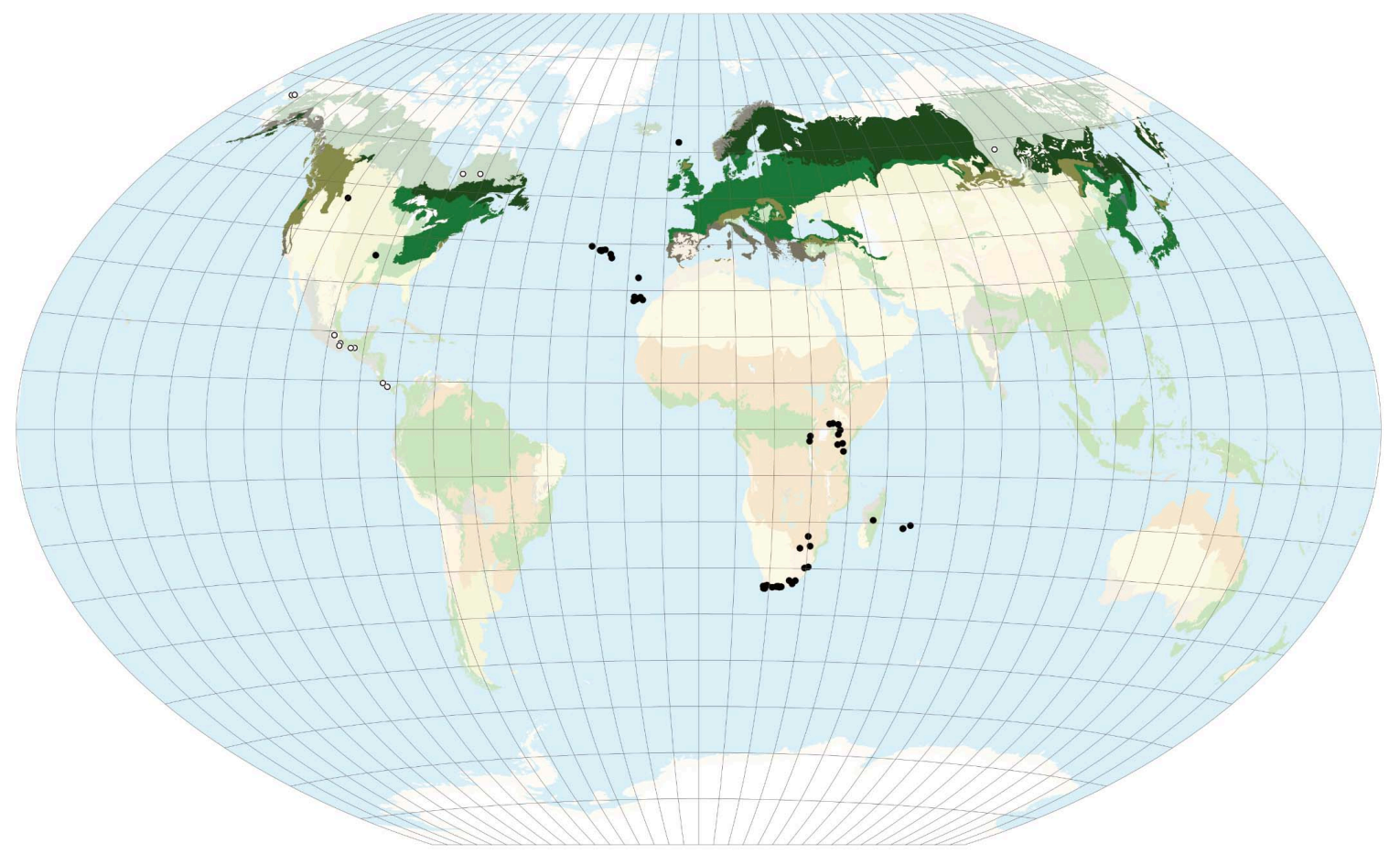

Tropical and subtropical moist broadleaf forests Tropical and subtropical dry broadleaf forests Tropical and subtropical coniferous forests Tropical and subtropical grasslands and savannas Montane grasslands and shrublands Deserts and xeric shrublands

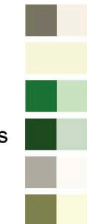

Mediterranean forests, woodlands and scrubs Temperate grasslands, savannas and shrublands Temperate broadleaf and mixed forest Boreal forests/Taiga Tundra

Temperate montane forests
Snow, ice, glacier and rocks

Flooded grasslands and savannas Mangroves

Water

FIGURE 3 | Distribution map of L. pulmonaria created with ArcGIS 10. Colors indicate the different vegetation zones. Strongly colored areas - general distribution regions. Solid dots - single occurrence spots. Open dots - occurrence not clarified. L. pulmonaria has a worldwide distribution mainly occurring in the Northern Hemisphere.

\section{Molecular Tools to Investigate Lichen-Associated Microorganisms The Rise of 'Omics' Technologies}

Lichen-associated bacteria were initially identified and investigated describing bacteria by their phenotypical and physiological characterizations (Cengia Sambo, 1926; Iskina, 1938; Panosyan and Nikogosyan, 1966; Henkel and Plotnikova, 1973; Lenova and Blum, 1983). Later, molecular techniques using bacterial isolates were conducted (González et al., 2005; Cardinale et al., 2006; Liba et al., 2006; Selbmann et al., 2010). However, culture-dependent methods generally capture only a minor fraction of the bacterial diversity of environmental samples (Amann et al., 1995). Therefore, new techniques were elaborated and the first culture-independent investigations, such as fingerprinting methods (Cardinale et al., 2006, 2012a; Grube et al., 2009; Bjelland et al., 2011; Mushegian et al., 2011) or molecular cloning approaches (Hodkinson and Lutzoni, 2009), were started to generate microbial community profiles. A further advantage of these methods is the possibility to analyze many samples in parallel and to compare their profiles consistently. Using the pyrosequencing method, several DNA-based studies described lichen-associated bacterial communities (Bates et al., 2011; Grube et al., 2012; Hodkinson et al., 2012; Aschenbrenner et al., 2014).

By improvement of the sequencing methods and bioinformatic tools, research focus shifted to a more detailed and holistic view on lichen microbial communities. In this respect, the lichen microbiome can be studied using a diverse spectrum of 'omics' technologies (Figure 4). Despite metagenomic analyses (e.g., Grube et al., 2015; Cernava et al., 2015; Aschenbrenner et al., 2017; Cernava et al., 2018; Graham et al., 2018), many studies applied metatranscriptomic (e.g., Cernava et al., 2017, 2019) and metaproteomic (e.g., Berg et al., 2011; Schneider et al., 2011; Grube et al., 2015; Cernava et al., 2017; Eymann et al., 2017; Ullah et al., 2020) approaches to study lichen symbioses.

\section{(Meta)Genomics: Accessing Life's Blueprint}

The total genetic information (encoded by DNA) of an organism is defined as its genome and all genomes within a habitat form the habitat's metagenome. Despite long-term evolutionary processes the environment has only minor influence on the DNA structure and information content (Figure 4). Due to DNA's stability and its 

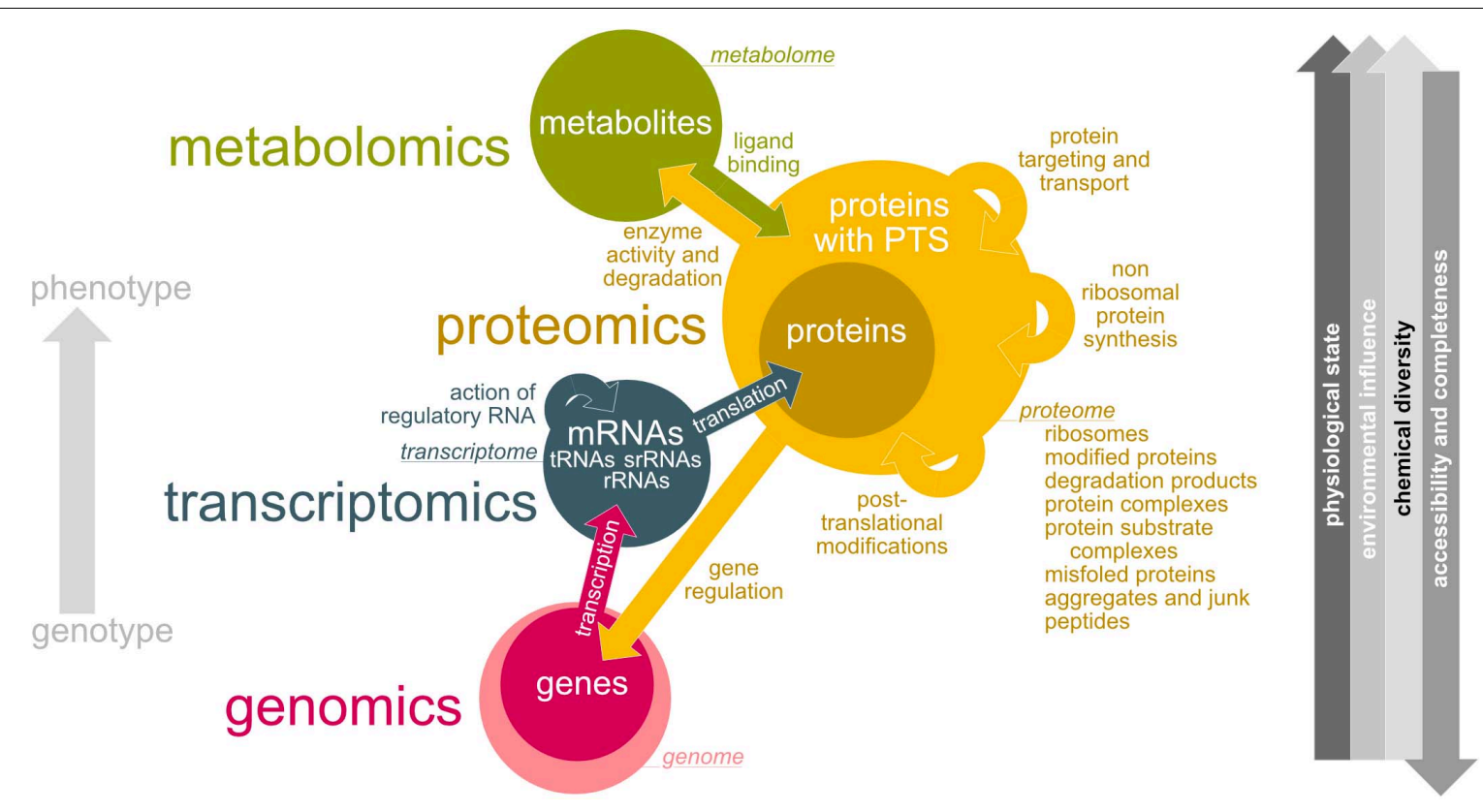

FIGURE 4 | Overview about '-omics' technologies used for lichen microbiome research. Green - metabolomics, yellow - proteomics, blue - transcriptomics, pink genomics. Colored arrows indicate interactions between metabolome, proteome, transcriptome and genome and how they are affecting each other. Circle sizes illustrate estimated complexity. Gray arrow direction (right hand side) implies an increase.

low chemical diversity, methods for extraction, preparation and sequencing became routinely applicable (Figure 4). Genomics reads, assembles, stores and interpretes the DNA-encoded information and is important to understand the organization, structure and function of genes of an organism.

Metagenomic analyses of lichen microbiomes (Cernava et al., 2015; Aschenbrenner et al., 2017; Cernava et al., 2018; Graham et al., 2018) identify (gene)sequences covering a wide range of potential bacterial functions with possible impact on the symbiotic system and their assignments to the taxa which are present. However, metagenomics does not provide information whether these functions are specifically expressed by any of these bacteria under the given environmental conditions. However, this knowledge is required to understand how the microbiome responds to changing conditions in the lichens natural habitats.

Metagenomic analyses are currently dominated by high throughput sequencing of relatively short reads, but they are shorter than most genes and thus, read-based methods cannot provide sufficient information about the genomic organization of genes. Huge amounts of previously uncharacterized genomic diversity can be unveiled by creating metagenome-assembled genomes (MAGs; Parks et al., 2017; Maguire et al., 2020). Thereby, contigs are assigned to clusters or so-called "bins" based on their similarities in relative abundance and sequence composition parameters such as frequencies of nucleotide tuples (di-, tri-nucleotides). The creation of MAGs including tools are reviewed by Sangwan et al. (2016). The MAG approach has been successfully applied to a wide range of environments, e.g., aquatic habits (Narasingarao et al., 2012). For the first time, Wicaksono et al. (2020) reconstructed 29 bacterial MAGs (contamination < 10\%) from metagenomes of lichens (17 MAGs: L. pulmonaria, 7 MAGs: C. furcata and 5 MAGs: P. polydactylon). Most of the created MAGs were assigned to Proteobacteria. This study indicates that creating MAGs can be crucial for further exploration of the ecological role of bacterial symbionts in lichens. The comparison of metagenomic data with those derived from other 'omics' techniques reveal that only a fraction of bacteria is active in lichens at the same time (Grube et al., 2015). Furthermore, MAGs could help analyze the utilization potential of complex carbohydrates by bacteria (Hassa et al., 2018).

\section{(Meta)Transcriptomics: Determining Active Genes}

The transcriptome is the total RNA transcribed from the genome of an organism at a given time point. Thus, the composition of the transcriptome directly reflects the entirety of external environmental stimuli on gene expression level (Figure 4). Due to the lack of available complete (meta)genomes only RNASeq (the determination of short cDNA sequence reads) is applicable for metatranscriptome studies of more complex biological systems such as lichens. Nevertheless, the availability of reference genomes would dramatically support the differentiation of transcripts between host and microbial RNA (Aguiar-Pulido et al., 2016).

Environmental metatranscriptomics focuses on mRNA to estimate the expressed genes in a given community and thus, helps to identify active metabolic pathways functioning under specific environmental conditions.

Cernava et al. (2017) analyzed the functional diversification of the microbiome of $L$. pulmonaria using a meta-omics approach. By using metatranscriptomics in addition to metagenomics and -proteomics facilitate the detection of so far unknown bacterial 
species in the lichen symbiosis. Metatranscriptomics as well as metagenomics revealed various strategies of lichen-associated bacteria to survive under stress conditions. The data derived from metaproteomic analyses can validate and corroborate metagenomic or -proteomic results.

Recently, Cernava et al. (2019) studied the role of lichenassociated microorganisms (L. pulmonaria) in enduring dehydration and drought using a metaproteomics approach. They revealed that the microbiome is well-adapted to dehydration by stress protection and additionally changes of the metabolism. Furthermore, an interplay in holobiont functioning under drought stress is indicated by their results.

The high abundance of ribosomal RNA in mRNA preparations may reduce the RNASeq coverage and the instability of mRNA in general has to be considered appropriately in metatranscriptomics.

\section{(Meta)Proteomics: Seeing the Blueprint at Work}

Proteins are synthesized by translating the available and intact mRNAs (Figure 4). By this reason, only the complement of active genes (mRNAs) also occurs on protein level. According to varying sequence length, the protein composition from 20 amino acids recombines the amino acid's chemical properties. After translation, proteins may undergo wanted but also arbitrary chemical modifications such as phosphorylations and many others, site-specific cleavage, aggregation with other proteins or prosthetic groups. Transport processes may remove proteins from the analyzed sample. Unstable proteins will be rapidly degraded while proteins with long half lifes will last from several days until years. This results in protein-to-protein concentration differences covering several orders of magnitude. All of this impacts single protein molecules but also the composition of the protein pool at all. This explains why the proteome - the entirety of all proteins of a biological system at a given time point at a defined developmental stage under defined environmental conditions - is one of the most complex and dynamic biological entities under investigation we may need to handle. Covering all proteins in one experimental setup for the analysis of (meta)proteomes is not possible. Especially less abundant proteins below detection threshold and proteins tending to form complexes, to precipitate, or to bind to surfaces of sample particles or lab equipment may escape analysis or make an enrichment or adaptations of sample preparation protocols necessary.

For liquid chromatography mass spectrometry (LCMS) based proteomics, extracted proteins are enzymatic cleaved for generating peptides which subsequently can be ionized and massanalyzed (Karpievitch et al., 2010). With tandem MS (MSMS) devices sequencing of higher abundant peptides is performed. The determined masses, sequence tags and signal strengths of peptides are then assigned to protein sequences.

For correctly assigning peptide data to proteins, a suitable bioinformatic workflow including the selection of an appropriate database is of fundamental importance (Heyer et al., 2017). Such databases are made from a collection of protein sequences, which are expected to be found in the analyzed sample. Usually one considers protein sequences from taxonomic and metagenomic analyses of comparable samples (Kunath et al., 2019). Including sequenced mRNA in the database allows us to focus on the active part of the genes/community (Hassa et al., 2018; Kunath et al., 2019). If only sequences of model organisms or any other biased data were used for database construction the peptide masses of unknown taxa will produce incorrect sequence hits or no hits at all.

After assignment of measured mass signals and sequence tags to peptides and peptides to proteins, the total quantities of single proteins by summing up all peptide signals is possible. The final result per sample will have determined the quantitative distribution of proteins. Species specific and functional protein assignments may reveal, which constituents of an analyzed sample are specialized to fulfill specific functions (Eymann et al., 2017). Per taxon quantification of all assigned proteins may show, to which extent each taxon contributes to the whole system on protein level (Eymann et al., 2017).

Putting the data of a set of samples together may allow binary sample-to-sample comparisons or the extraction of protein expression profiles along spatial or other environmental gradients. Such kind of differential metaproteome analysis could help for understanding the responses of microbial communities as an entirety to changing conditions and can thus provide information about community resistance and resilience under environmental stress. Schiebenhoefer et al. (2019) discuss appropriate bioinformatic tools for metaproteomic analysis.

More recent developments which are based on differential detection of peptides with different stable isotope composition offer fascinating opportunities to elucidate metabolically active taxa and metabolite fluxes within microbial communities (for an outlook see Kleiner, 2019). For stable isotope probing (SIP) labeled substrates such as sugars and carbon compounds or amino acids containing ${ }^{13} \mathrm{C},{ }^{15} \mathrm{~N},{ }^{18} \mathrm{O}$ or ${ }^{36} \mathrm{~S}$ respectively are applied. Active cells take up the labeled substrates, which can be later detected within the proteins via MS. The rate of incorporation in defined taxa of the investigated sample community can be used for assessing their metabolic activity or their preferences for the applied substrate (Seifert et al., 2012; Von Bergen et al., 2013).

Stable isotope fingerprinting (SIF) is an approach similar in principle, but circumvents the artificial application of labeled substrates. Due to naturally occuring carbon isotope discriminative effects against ${ }^{13} \mathrm{C}$ in $\mathrm{C} 1$ pathways (e.g., for assimilation of bicarbonate, $\mathrm{CO}_{2}$, or methane), metabolites and biomass originating from these pathways show an altered carbon isotope $\left({ }^{13} \mathrm{C} /{ }^{12} \mathrm{C}\right.$, commonly called $\left.\delta \mathrm{C}\right)$ ratio that can be used to reveal chemical fluxes and dependencies within metaproteome samples (Jehmlich et al., 2016). The software Calis-p supporting the direct extraction of species-specific $\delta \mathrm{Cs}$ from standard metaproteome datasets was presented and made available (Kleiner et al., 2018). To our knowledge, SIP as well as SIF were not applied to lichens until now.

\section{Metabolomics: Analyzing Enzyme's Action}

Proteins interact with each other resulting in a complex metabolic system of an organism. Changes in the proteome lead to changes in the metabolome. Thus, the metabolome is highly dynamic and 
complex (Figure 4). Changes can develop in fractions of seconds making metabolome analysis and sample preparation a very challenging task. Metabolites can additionally act as cofactors, signaling molecules, substrates or stabilizing agents for proteins. Metabolomics determines a sample's profile of metabolites at a defined time point under certain environmental conditions (Figure 4). Metabolomics may play a role to examine the available metabolites of the lichen and its microbiome.

Antibiotic effects of a number of lichen metabolites against gram-positive bacteria is known since long (reviewed, e.g., in Shrestha and Clair, 2013), and presumably, such compounds could regulate bacterial growth in lichens. A disadvantage of metabolomics in contrast to metaproteomics is the fact that it is challenging to assign metabolites to specific taxa, due to the lack of taxon-specific signatures for metabolites.

While for homogenous microbial cultures, protocols for rapid sample processing for immediate metabolome access are available, this needs still to be established for complex systems such as lichens. With current protocols at hand only stable metabolites such as secondary metabolites including those of bacteria (Boustie and Grube, 2005), polymeric compounds or compounds terminating metabolic build-up pathways may be reliably accessed and quantified.

One method to study metabolic pathways and fluxes of lichens in vivo is based on the utilization of stable isotope labeling. They are based on the supply of the labeled tracer to the growth medium (Kuhn et al., 2019). The positional labeling patterns can reveal the biosynthetic history of the studied products (Kinoshita et al., 2015). Labeling studies of intact lichens are challenging, because the symbiosis between photo- and mycobionts could trigger the metabolism of both (Calcott et al., 2018), but several projects engaged in this subject. Experimentation with ${ }^{14} \mathrm{C}$ was popular in lichen physiology mainly for studying carbohydrate transfer (e.g., Richardson et al., 1968), but declined since then, while more recent studies favor the use of ${ }^{13} \mathrm{C}$ in experiments. Lines et al. (1989) conducted ${ }^{13} \mathrm{C}-\mathrm{NMR}$ analysis and revealed the transport of ${ }^{13} \mathrm{C}$-photosynthate from the photo- into the mycobiont of $X$. calciola for mannitol biosynthesis. Sundberg et al. (1999) showed that there may be significant differences in carbon transfer rates and partitioning of carbon between the symbionts in different lichen (e.g., L. pulmonaria) by using ${ }^{13} \mathrm{C}-\mathrm{NMR}$ spectroscopy in combination with ${ }^{13} \mathrm{CO}_{2}$ labeling. Aubert et al. (2007) identified 30 metabolites in $X$. elegans using ${ }^{13} \mathrm{C}$ - and ${ }^{31} \mathrm{P}$-NMR spectroscopy and with that indicated that metabolite composition is affected by stress conditions. An additional study reveals that cyano- and tripartite lichens have a strong respiratory response to glucose by conducting carbon dioxide flux measurements and phospholipid acid analysis with experimental application of ${ }^{13} \mathrm{C}_{6}$ (Campbell et al., 2013). Recently, Kuhn et al. (2019) performed in vivo labeling experiments with Usnea dasypoga using ${ }^{13} \mathrm{CO}_{2}$ or $\left[\mathrm{U}_{-}{ }^{13} \mathrm{CO}_{6}\right]$ glucose and reconstructed the biosynthetic pathway of usnic acid.

Non-canonical amino acids (NCAAs), or "unnatural amino acids," are identified in several microorganisms. Noncanonical D-amino acids (NCDAAs) are secreted by various bacteria as signaling molecules to aid the bacteria to cope with changing environmental conditions (Lam et al., 2009;
Kolodkin-Gal et al., 2010; Leiman et al., 2013). Cava et al. (2011) indicate that NCDAAs cause biofilm dispersal in aging bacterial communities. NCAAs are additionally involved in the formation of cyanobacterial hepatotoxins. In recent studies, the hepatotoxins microcystin-LR and nodularin were frequently found in lichen cyanobionts (Oksanen et al., 2004; Kaasalainen et al., 2009, 2012). Such toxins can have grazing inhibition effects and therefore may protect the lichen against herbivory (Hrouzek, 2017). Labeling studies using NCAAs are known from several proteomic and biotechnological studies, because it benefits from the ability to enrich labeled proteins. Saleh et al. (2019) recently reviewed this method. However, to our knowledge this method was not used in lichen metabolite studies so far.

\section{Molecular Imaging: Visualizing Interactions in situ}

By combining the different omics approaches with imaging techniques previously overlooked participants, metabolites and the spatial occurrence of both can be found in lichens.

With fluorescence in situ hybridization (FISH) specific nucleic acid sequences can be detected and localized by using fluorescent probes. It can be used to uncover the taxonomical and spatial structure of bacterial communities in lichens (e.g., Cardinale et al., 2008; Muggia et al., 2013; Maier et al., 2014; Erlacher et al., 2015; Cernava et al., 2017). Levsky and Singer (2003) reviewed the methodology.

With matrix-assisted laser desorption/ionization (MALDI) imaging mass spectrometry (IMS), the distribution of proteins and small molecules within biological systems can be investigated by in situ analysis of thin tissue sections. It can determine the distribution of hundreds of compounds in only a single measurement and enables the acquisition of cellular expression profiles without destroying the cellular and molecular integrity. Cornett et al. (2007) and Walch et al. (2008) reviewed the methodology. In lichens, IMS can be used to visualize the distribution of secondary compounds, which was first shown by Le Pogam et al. (2016). Linking imaging mass spectrometry with metagenomics can determine the localization and organization of small molecules within the microbial community of lichens. For example, an ordered layering of molecules assigned to specific lichen symbiotic partners can be revealed (Garg et al., 2016).

\section{The Bacterial Community of L. pulmonaria Where Bacteria Reside Within the Lichen Thallus}

The surface of lichens, best studied in L. pulmonaria and C. arbuscula, is densely colonized by bacteria (Figure 1; Cardinale et al., 2008, 2012a,b; Grube et al., 2009; Schneider et al., 2011). The density of bacteria on lichen thalli (e.g., Cladonia rangifera: c. $10^{7}-10^{8}$ cells $/ \mathrm{g}$ ) is higher in relation to surfaces of higher plants (leaf surface: c. $10^{5}$ cells $/ \mathrm{cm}^{2}$ ) (Cardinale et al., 2008; Grube et al., 2009; Saleem, 2015).

The Alpha diversities (Shannon index) of bacterial communities can vary between different lichens. L. pulmonaria shows an index of 7.0 whereas Solorina crocea an index of 4.5 (Grube et al., 2012; Aschenbrenner et al., 2014).

Lichen associated bacteria colonize distinct thallus parts in various abundances and patterns due to chemically and 
physiologically differences. Alphaproteobacteria are widespread on both the upper and lower surface of $L$. pulmonaria (Cardinale et al., 2012a; Grube et al., 2015). This is also demonstrated for other dorsoventrally organized lichen species, like Umbilicaria sp. (Grube et al., 2015). In contrast to Alphaproteobacteria, Betaproteobacteria are locally restricted on the lower surface (Grube et al., 2015). For Cladonia species, the highest amount of bacteria is found on the internal layer of the podetia (Cardinale et al., 2008, 2012b), whereas bacterial colonization on crustose lichens (e.g., Lecanora sp.) is higher in the cracks and fissures between the areoles of the crustose thalli (Grube et al., 2009), perhaps because humidity stays longer. Cardinale et al. (2008) found evidence for bacterial presence in cell walls of $C$. arbuscula, but not in the cytoplasm. Unsurprisingly, bacteria are also found on decaying lichen material of some terricolous lichens, like Baeomyces rufus or C. rangiferina, or in the lichen-substrate interface (Asta et al., 2001). In their study of the lichen genus Xanthoparmelia, Mushegian et al. (2011) found that the older central parts of this leaf-like lichen contain a richer and more stable bacteria community than the younger thallus periphery. This is partly confirmed by a study from Cardinale et al. (2012b) and Noh et al. (2020) for the upright thalli of Cladonia sp. The microbiome shows an increase in diversity from apical to basal parts and significant differences according to the vertical position within the thallus.

\section{Microbiome Functions Overview}

The lichen microbiome may contribute multiple functions to the lichen symbiotic system (Figure 5) (Hunter, 2006; Grube et al., 2015; Eymann et al., 2017). This includes essential functions such as nutrient supply by uptake and/or assimilation of e.g., iron, phosphate, sulfur, amino acids and dipeptides, sugar and xylose (e.g., Sphingomonadales, Burkholderia or Acetobacteraceae), resistance against abiotic factors (e.g., toxic environmental compounds, oxidative or osmotic stress; Chtoniobacterales, Rhodospirillales, Myxococcales), growth hormone production or nitrogen fixation (Figure 5; Liba et al., 2006; Grube et al., 2009, 2015; Schneider et al., 2011; Cardinale et al., 2012a; Erlacher et al., 2015; Cernava et al., 2017).

Grube et al. (2015) reveal that Alphaproteobacteria covered up to $50 \%$ of the microbiome functions in L. pulmonaria, e.g., production of amino acids or vitamins, carbohydrate metabolism, stress response or protein degradation. Proteobacteria and Bacteroidetes are involved in iron uptake. Ton and Tol transport systems and especially TonB-dependent receptors are revealed by metagenomic and -proteomic analyses. The amount of bacterial functions serving the self-preservation of the microbes or the entire lichen has to be elucidated in more detail in the future.

\section{Uptake and supply of nutrients, essential compounds and trace elements}

Bacteria can influence the growth of their host by e.g., producing growth hormones. This is supported by the identification of genes/proteins of the bacterial microbiome of L. pulmonaria (Grube et al., 2009) involved in auxin biosynthesis. The mobilization and recycling of material from senescent thallus parts may facilitate growth of the young and growing thallus parts (Grube and Berg, 2009; Grube et al., 2015; Cernava et al., 2017; Eymann et al., 2017).

Granulicella and Lichenibacter are lichen-associated bacteria for which carbohydrate use and production are known (Pankratov and Dedysh, 2010; Pankratov et al., 2019). The first one, the genus Granulicella, hydrolyzes pectin, xylan, laminarin and lichenan and produces an amorphous EPS matrix composed of polysaccharides in Cladonia lichens (Pankratov and Dedysh, 2010). Lichenibacter utilizes starch and xylan (Pankratov et al., 2019).

The role of bacterial strains (e.g., Azospirillum, Bradyrhizobium and Frankia) for supplements of fixed nitrogen to the symbiotic partners is obvious. Creating a partial anaerobic biofilm as bacterial habitat is important for bacterial nitrogen fixation, which may augment the nitrogen budget in lichens lacking a N-compound-donating cyanobiont. Several lichenassociated bacteria, like Alphaproteobacteria (Grube et al., 2009; Almendras et al., 2018), Gammaproteobacteria (Liba et al., 2006), Firmicutes (Grube et al., 2009; Almendras et al., 2018) and Actinobacteria (Almendras et al., 2018) contain nifH genes. In the case of $\mathrm{N}$-limiting conditions, bacterial $\mathrm{N}$-fixation, by e.g., Azotobacter, Betaproteobacteria or Alphaproteobacteria, could be of considerable importance for the vitality of lichens (Leveau and Preston, 2008; Grube and Berg, 2009; Grube et al., 2009; Bates et al., 2011; Erlacher et al., 2015). This fits well with studies of Almendras et al. (2018) showing that Chlorolichens have a higher diversity of $\mathrm{N}$-fixing bacteria than cyanolichens. However, nitrogen supply is not a problem in many parts of Europe, as the atmosphere carries massive amounts of nitrogen compounds from agriculture over large distances.

Many algae are auxotrophic for vitamin $\mathrm{B}_{12}$ that is often synthesized by bacteria in symbiotic communities (Croft et al., 2005). Bacteria (e.g., Chtoniobacterales, Sphingomonadales, Sphingobacteriales, Myxococcales, and Rhizobiales) may be of importance for cofactor and vitamin synthesis and supplementation of the whole symbiotic system. Bacterial enzymes are found in L. pulmonaria, which are involved in the synthesis of cobalamin belonging to the Vitamin B12 group (relevant for photosynthesis), biotin (Vitamin B7; important for gene regulation), folate (Vitamin B9/B11; important for $\mathrm{C}_{1}$-metabolism), pantothenate (Vitamin B5; synthesis and degradation of carbohydrates) or pyridine (herbicide production) precursors supporting fungal growth (Erlacher et al., 2015; Grube et al., 2015).

We suggest that lichens, which can live up to hundreds of years, maintain a dynamic equilibrium of bacteria. The growing parts (alphaproteobacterial dominance) act as anabolic systems. The senescing parts might represent catabolic sinks. Cardinale et al. (2012b) assume that the bacteria, which are colonizing the older lichen parts, help to convert the old lichen biomass into simple molecules. These will then be released into the substrate or can be recycled to the growing lichen parts as it was shown previously (Ellis et al., 2005). 


\section{Mycobiont}

\section{Who? Heterotrophic ascomycete}

Functions: forms upper and lower cortex (protection), medulla, cephalodia, tomenta, propagules; responsible for morphology and mechanical stability; Dispersal (builds symbiotic propagules (soredia and thallus fragments) for small distance and mycobiont ascospores for long distance)

General: hosts all symbiotic partners and provides mycobiont-symbiont interface as well as environmental interface; transports substances by repeated shrinkage and swelling; mannitol and poly-ol production from sugar alcohols for osmoprotection,

Algal support: holds algae in place; coats algae with a hydrophobic protein layer; controls incoming light by melanin or atranorin or natural curling; serves as $\mathrm{CO}_{2}$ reservoir for algal cells and produces $\mathrm{CO}_{2}$; taurine synthesis stimulates release of photobiont photosyntheates

Cyanobiont interaction: prevents oxygen from accessing cephalodia Microbiome interaction: shapes microbiome by producing depsides and depsidones as well as acidic secondary metabolites

\section{Photobiont}

Who? Autotrophic green alga Dictyochloropsis reticulata (family Trebouxiaceae) Where? forms algal photosynthetically active layer

Functions: photosynthethic carbon fixation by $\mathrm{Chl}$ a and $\mathrm{b}$; secretion of energy rich carbon compounds such as sugar alcohols and glucans via lichenized permeable cell wall; Beta-catenin enables algal to algal cell and algal to mycobiont cell signaling and substrate exchange

Microbiome interaction: type of carbon source shapes microbiome

Mycobiont: forces mycobiont to build a lichen of appropriate morphology

\section{Cyanobiont}

Who? auxotrophic cyanobacterium from Nostoc group

Where? in gall-like microaerobic structures (cephalodia)

Functions: $55 \%$ of Nostoc cells from colonies inside cephalodia form heterocysts for $\mathrm{N}_{2}$-fixation; carbon fixation and photosynthesis; $\mathrm{Chl} \mathrm{a}$ and $\mathrm{b}$ complementary light harvesting by phycobilines (phycobilisomes)

\section{Lichenicolous Fungi}

Who? heterogenous group of heterotrophic lichenicolous fungi

Where? in all linchen structures

Functions: the majority commensalic to weakly parasitic, a minority being strongly parasitic or destroving the host.; an essential role within the symbiontic system is controversily discussed, possibly involved in recycling, reorganization and reshaping the lichen thallus

\section{Microbiome}

Who? relatively stable community of mainly heterotrophic bacteria other than the population in the surrounding environment; population's diversity increases from apical (young) to basal (older) parts of thallus and is to a certain extent variable; mainly Alphaproteobacteria (including Rhizobiales especially Methylobacteriaceae, Bradyrhizobiaceae, Rhizobiaceae and especially Methylobacteriaceae, Bradyrrizzobiaceae, Rhizoblacea
Sphingomonadales) on upper and lower surface and in addition Actinobacteria, Betaproteobacteria on the lower cortex, Firmicutes or Deinococcus and some Archaea

Where? colonizing the outer cortex in a biofilm like fashion, to a certain extent also the hydrophilic regions of hyphal cell walls in the inner lichen, but rarely algal cells

Functions: Alphaproteobacteria cover up to $50 \%$ of the microbiome functions (production of amino acids or vitamins, carbohydrate metabolism, stress response or protein degradation). Proteobacteria and Bacteroidetes are involved in iron uptake. Ton and Tol transport systems and especially TonB-dependent receptors

Nutrient, vitamin and trace element supply: iron, phosphate, sulfur, amino acids and dipeptides, sugar and xylose (e.g. Sphingomonadales, Burkholderia or Acetobacteraceae), growth hormone (auxin) production or $\mathrm{N}_{2}$ fixation; recycling of senescent thallus and release of nutrients; $N_{2}$ fixation; recycling of senescent thallus and release of nutrients;
spermidine supply (Stenotrophomonas) supporting cell survival and spermidine supply (Stenotrophomonas) supporting cell survival and
protein recycling (autophagy); synthesis of cobalamine (Vit B12) for the auxotrophic algae, biotin (Vit B7), folate (Vit Bg/11), pantothenate (Vit B5) and pyridine

Resistance to abiotic factors: (e.g. toxic environmental compounds, oxidative or osmotic stress; Chtoniobacterales, Rhodospirillales, Myxococcales), detoxification of heavy metals (copper, cobalt-zinccadmium, silver, mercury and arsenic) and $\mathrm{C}_{1}$ compounds and $\mathrm{CO}$; resistance to oxidative stress

Antagonizing biotic impact: antimicrobial or antibiotic compounds (fluoroquinolone, vancomycin, methicillin, penicillin and cephalosporin) produced by Stenotrophomonas, Pseudomonas, Burkholderia and Actinobacteria

FIGURE 5 | Microbiome and symbiotic partner's functions in the lichen L. pulmonaria. The mycobiont is responsible for the holobionts' morphology, mechanical stability and reproduction, protects and supports the photo- and cyanobiont and shapes the microbial community. The photobiont is in charge of the photosynthetic carbon fixation. The cyanobiont is responsible for nitrogen and carbon fixation. The detailed role of the lichenicolous fungi is unclear. The microbiome plays a role in nutrient, vitamin and trace element supply, in resistance to abiotic factors and in antagonizing biotic impact.

\section{Abiotic stress and toxic compound protection}

The bacterial microbiome of L. pulmonaria (e.g., Chthoniobacterales, Myxococcales, Sphingomonadales, Sphingobacteriales) shows resistance against abiotic stressors (Grube et al., 2015; Cernava et al., 2017), but the detailed mechanisms remain mostly unknown. Cernava et al. (2018) show that the microbial community structures do not depend on the level of arsenic concentration at the sampling site, whereas the functional spectrum related to arsenic metabolism is enhanced. Furthermore, the amount of detoxification related genes is higher in arsenic-polluted samples. Additionally, oxidative-stress protectants to heavy metal efflux are observed (Grube et al., 2015). Besides creating anaerobic niches, EPS and thus biofilm formation may play a role in the protection against $\mathrm{pH}$ and metals as shown for Rhizobium leguminosarum, a soil bacterium that establishes symbiosis with Trifolium spp. (Kopycińska et al., 2018).

Besides confirming the resistance against abiotic stressors, the bacterial microbiome may help with the detoxification of methanol/ $\mathrm{C}_{1}$-metabolites. Formaldehydeactivating enzymes are highly abundant in bacterial samples, especially Methylobacteriaceae, of $L$. pulmonaria. These enzymes are involved in oxidation of methanol to carbon dioxide and formaldehyde detoxification. The assignment of carbon monoxide dehydrogenase to the same bacterial family in the metaproteomic analysis of L. pulmonaria indicates the existence of carbooxidotrophic bacteria or the detoxification of carbon monoxide, which competes with $\mathrm{O}_{2}$ for cytochromoxidase of the respiration chain (Eymann et al., 2017). 


\section{Antagonists of biotic impact}

Lobaria pulmonaria and potentially other lichens may be important reservoirs for bacteria acting against bacterial and fungal pathogens. In former studies, it was shown that Rhinocladiella sp. and Botrytis cinerea were inhibited by bacterial strains isolated from L. pulmonaria (Cernava et al., 2015). Rhinocladiella are black fungi that may opportunistically act as human pathogens and could for example cause cerebral phaeohyphomycosis (neurotropic fungus $R$. mackenziei) by infecting nerve cells (Jabeen et al., 2011; Didehdar et al., 2015). Botrytis cinerea is a plant pathogen causing the gray mold disease (Williamson et al., 2007). The defense against such pathogens is possible by secretion of protective substances such as antimicrobial or antibiotic compounds (vancomycin, penicillin and cephalosporin). Stenotrophomonas, Pseudomonas, Burkholderia and Actinobacteria dominate the abundant antagonistic community of L. pulmonaria as producers of bioactive volatiles (Cernava et al., 2015, 2017).

\section{Microbiome Acquisition and Shaping}

Little is known about the intraspecific variation of microbiome composition, and how lichens acquire their specific bacterial communities. A study of Aschenbrenner et al. (2014) indicate that the propagules of lichens contribute to a co-dispersal of lichen-associated bacteria (Figure 6), since the propagules (isidia) of $L$. pulmonaria share the overall bacterial community with the parental thalli at class level. This also suggests that the bacterial community structure might change over time at lower taxonomic ranks. Cardinale et al. (2012a) suppose that when propagules of $L$. pulmonaria are dispersed, the high-abundant Alphaproteobacteria are maintained for successful colonization of the new site. During colonization, both Burkholderia and nitrogen fixers will be lost, and local, better-adapted competitors may be picked up from the new environment.

The prokaryotic community may be recruited from "bacterial rain", as for example known from phyllosphere microbiomes

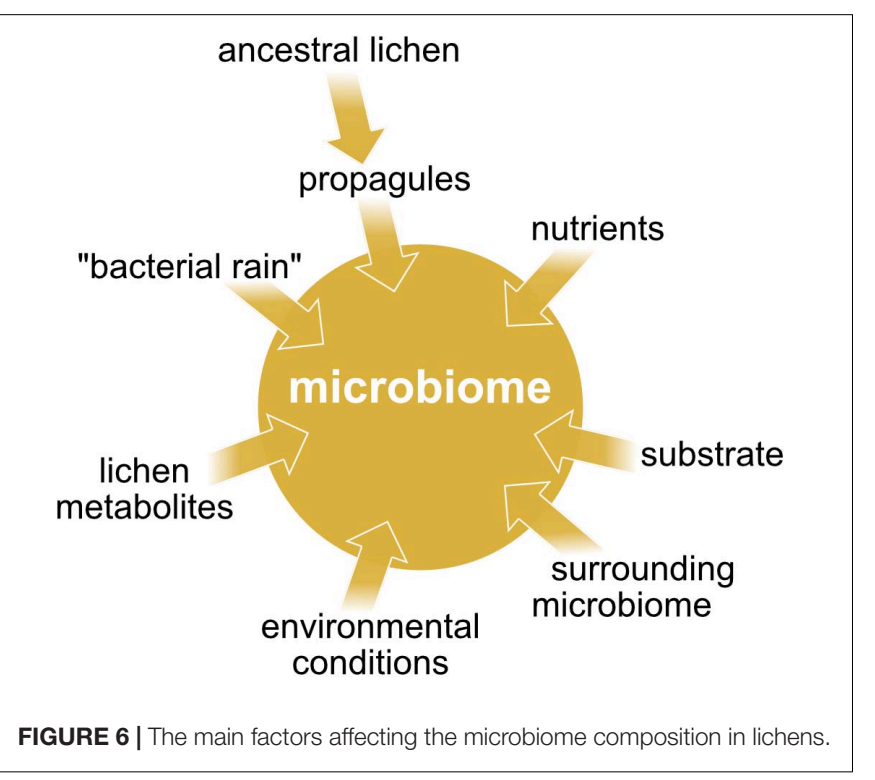

(Mechan Llontop, 2020), or from the adjacent substrate (Figure 6). Uptake of cyanobacterial photobionts from mosses growing around L. pulmonaria thalli was indicated by a study of Aschenbrenner et al. (2014). The mosses provide the cyanobacteria to the lichen propagules and young lichen thalli respectively. Cyanobacterial uptake from neighboring mosses was also demonstrated for the lichen Erioderma pedicellatum (Cornejo et al., 2005). Recently, Aschenbrenner et al. (2017) indicated that mosses growing around L. pulmonaria thalli may generally facilitate bacterial colonization of this lichen species. Additionally, they demonstrated that the bark microbiome of the inhabited tree species shares partly the same bacterial taxa with the lichen microbiome.

It is shown that the composition of the microbial communities is lichen specific (Grube et al., 2009; Bates et al., 2011; Hodkinson et al., 2012). On the lichens surfaces, a mixture of both abiotic and biotic conditions possibly controls bacterial growth. The poikilohydric conditions, with recurrent desiccation, may prevent the persistence of fast growing bacterial opportunists. Furthermore, it is known that rehydration following a desiccation period causes an oxidative burst by induction of high rates of superoxide production by the mycobiont. We argue this affects the bacterial microbiome or mycobiome and could select for survival of superoxide resistant bacteria, while the killed bacteria may serve as a nutrient source to support further lichen biomass production after rehydration.

Reports about antibacterial effects of lichen compounds or extracts (Burkholder et al., 1944; Ingólfsdóttir et al., 1998; Francolini et al., 2004; Boustie and Grube, 2005) suggest a biotic lichen originated control (Figure 6). These compounds may have antibiotic or rather antimicrobial properties and therefore may play an active role in selecting for specific types of bacteria. Among those biorelevant compounds you can find polyphenols such as depsides and depsidones, but also lactones, anthraquinones etc. (Hodkinson et al., 2012). Lichens producing substantial amounts of acidic secondary metabolites have significantly different bacterial communities than others (Grube and Berg, 2009). L. pulmonaria contains lower concentrations of such lichen-specific substances than many other Peltigerineae lichens (Beckett et al., 2003). Grube et al. (2015) hypothesize that bacterial colonization is mostly regulated by the mycobiont because they found only little evidence for quorum sensing in the microbiome of L. pulmonaria.

Besides secondary metabolites, the availability of nutrients may affect the microbial community (Figure 6). There is a significant correlation between photobiont-type and bacterial community composition. This is due to the major difference between cyanolichens and chlorolichens in the availability of fixed nitrogen (Hodkinson et al., 2012). Bacteria that are associated with cyanolichens have access to fixed nitrogen whereas bacteria of chlorolichens lack this benefit. Presumably, chlorolichens enrich bacterial species, which are capable of nitrogen fixation. Details of carbon release may play an additional role in shaping the prokaryotic community. Lichen-associated green algae release fixed carbon as sugar alcohols, contrary to glucose release of cyanobacteria. The bacterial utilization of sugar alcohols requires an adapted set of enzymes such as 
polyol dehydrogenases. For this reason, prokaryotic communities associated with chlorolichens consist of bacteria, which are able to synthesize sugar alcohol specific transporters and degrading enzymes while glucose degradation in cyanolichens does not need bacteria with adapted enzyme panels (Palmqvist, 2002; Adams et al., 2006; Hodkinson et al., 2012).

Metabolic processes can additionally modulate and organize complex microbial community structures by exchange of nutrients. Spatial concentration gradients of metabolites in biofilms lead to a varying nutrient availability and therefore could regulate the distribution of species (Cardinale et al., 2002; Stewart and Franklin, 2008). A diverse spectrum of chemical gradients can be established, like oxygen, nutrient or bacterial signaling compound gradients. The adaptation of the bacterial microorganisms to these gradients includes differences in gene expression and thus protein production (Stewart and Franklin, 2008). By competing for nutrients, metabolic tasks in a community can be divided. Therefore, the population can spatially differentiate in different sections such as metabolically active and inactive microbial cells (Liu et al., 2015). The exchange of nutrients is suggested to maintain genotypic diversity within naturally bacterial communities (Germerodt et al., 2016). To our best knowledge, there is no information about cross-feeding in lichen biofilms. As it is common in the microbial world (Pande et al., 2014), we suppose nutrient exchange also occurs in lichen biofilms.

\section{Microbiome Diversity and Adaptability}

Functional diversification in L. pulmonaria, due to a multiplayer network of the symbiotic partners supports longevity and persistence under changing environmental conditions (Grube et al., 2015). Lichen-associated bacteria seem to be influenced by climatically or geographically differences. The geographical patterning is defined by dispersal on a larger scale where host dispersal could be the limiting factor (Hodkinson et al., 2012). In L. pulmonaria, the diversity of Alphaproteobacteria is affected by geography. Burkholderia ssp. and nitrogen fixers are mostly taken up from the local environment (Cardinale et al., 2012a). Eymann et al. (2017) compared two different sampling sites of L. pulmonaria (Darß, Germany and Styria, Austria) and suggested the presence of a relatively stable core microbiome. There are differences in the distribution of families within the Alphaproteobacteria order Rhizobiales. Actinobacteria were more abundant in the samples collected from Darß and Acidobacteria and Planctomycetes were more abundant in the samples collected in Styria. The study indicates significant differences between the proteomes of the two lichen microbiomes in contrast to the rather stable fungal and algal protein profiles. For example, cold shock proteins were more abundant in the Styria lichen material. A study of Hodkinson et al. (2012) reveals that the major bacterial community is correlated with differences in largescale geography. Printzen et al. (2012) found a less diverse microbial community of the lichen Cetraria aculeata in polar habitats. Antarctic and arctic communities are more similar to each other compared to samples from other regions such as Germany and Spain.
To understand how the extant microbiome responds to fluctuating environmental conditions in the natural habitats, Cernava et al. (2019) sampled lichens under representative hydration stages. Bacterial metatranscriptomes from L. pulmonaria reveal significant structural shifts and functional specialization corresponding to lichen hydration stages. The hydrated stage is correlated with upregulated transcription of transport systems, tRNA modification and various porins (Omp2b by Rhizobiales), whereas the desiccated samples suggest stress-adaptive responses. Carbohydrate metabolism is activated under both conditions, but under dry conditions, upregulation of a specialized ketone metabolism indicates a switch to lipid-based nutrition, reminiscent of 'fasting metaorganism.'

The possibility that the bacterial microbiome composition and functionality change according to ecological and climatic variations, could lead to an increase in the adaptivity of the holobiont. The adaptation of lichen populations to new habitats is presumably accompanied by changes in the bacterial communities similar to previously observed switches of the photobiont strain correlating with different ecological conditions (Blaha et al., 2006; Grube and Berg, 2009). Photobiont switches can be beneficial for the mycobiont if the locally occurring photobiont strains are better adapted to the environmental conditions at a particular site than the carried photobiont strain. In such cases the adapted photobiont strain will be incorporated into the lichen during thallus establishment (Werth and Sork, 2010; Wornik and Grube, 2010; Werth and Scheidegger, 2012).

Klarenberg et al. (2020) provide evidence of compositional shifts in individual taxa of the microbiome of Cetraria islandica due to climatic warming. Warming alters the abundance of the most common taxa such as Granulicella or Endobacter. The abundance of Granulicella or Bryocella is decreasing whereas the abundance of Acidisphaera, Sphingomonas and Endobacter is increasing. After long warming periods bacterial microbiomes can acclimatize and therefore shift back to the original composition (Bradford et al., 2008; Crowther and Bradford, 2013; Romero-Olivares et al., 2017). Warming periods also affect the amount of lichen secondary metabolites and can therefore have an effect on the composition of the lichen microbiome. Usnic acid concentration is increasing during warming and perlatolic acid concentration is reduced (Asplund et al., 2017). Usnic acid acts as an antimicrobial protectant against fungal parasites, like Fusarium moniliforme (Cardarelli et al., 1997), which is involved in several human and animal diseases and produces different toxins (reviewed by Nelson, 1992). Despite that, usnic acid plays an additional role in protection against indicator bacteria such as Staphylococcus aureus or Enterococcus faecalis (Lauterwein et al., 1995). Perlatolic acid is also showing antibacterial, e.g., against S. aureus or Escherichia coli (Piovano et al., 2002; Gianini et al., 2008) and antifungal activities such as against Cladosporium sphaerospermum (Gianini et al., 2008).

Cardinale et al. (2012b) found out that lichens (e.g., L. pulmonaria or C. arbuscula) harbor higher numbers of bacteria when growing under shaded conditions. Despite that, lichens growing on rock harbor fewer bacteria than lichens growing on soil or bark. It seems that the amount of bacteria may be associated with the humidity of the habitat. 


\section{Biotechnological Potential}

Lichens tolerate extreme abiotic stressors (e.g., extreme climates or osmotic conditions) and accumulate toxic compounds, heavy metals or radionuclides. Therefore, they could be sources of biotechnologically interesting strains, compounds and enzymes (Davies et al., 2002, 2005; González et al., 2005; Grube and Berg, 2009). Most lichen secondary metabolites are of fungal origin, e.g., stictic acid as herbivory protectant (Elix and Stocker-Wörgötter, 1996), but evidence for a bacterial origin is already found. González et al. (2005) published a study focusing on lichen-associated Actinobacteria and their bioactivity. A large number of strains were obtained. Several strains belonged to the family Streptomycetaceae that is well known to produce bioactive compounds. Other actinobacterial families, which are also known for the production of bioactive compounds, such as Micromonosporaceae, Pseudonocardiaceae, and Thermomonosporaceae, were also isolated. About 30\% of the strains showed antimicrobial activity against other microorganisms. The presence of some structurally identified bioactive molecules is reported for a few bacterial strains although there are many other strains of relevance (Cardinale et al., 2006; Liba et al., 2006; Grube et al., 2009; Selbmann et al., 2010; Pankratov, 2012; Kim et al., 2014; Lee et al., 2014; Sigurbjörnsdóttir et al., 2014; Cernava et al., 2015; Parrot et al., 2015). In the following paragraph, we summarize information about several lichen-associated bacteria producing already identified bioactive compounds.

An isolate of the dominant antagonistic genus Stenotrophomonas, found in the microbiome of L. pulmonaria, produces spermidine as the main bioactive compound (Cernava et al., 2015). Spermidine is a multifunctional polyamine that is a plant growth regulator, plays a critical role in plant embryo development and protects roots against stress (Al-Whaibi et al., 2012; Alavi et al., 2013). Additionally, spermidine affects biofilm formation in various bacterial species, like Vibrio cholerae (McGinnis et al., 2009), and acts as an antifungal biosynthesis regulator in Lysobacter enzymogenes (Chen et al., 2018). In eukaryotes, spermidine prolongs the life span and is known to play vital roles in cell survival, autophagy (the degradation of damaged and aggregated waste protein) and anti-aging (Eisenberg et al., 2009; Madeo et al., 2010, 2018). Tissue spermidine concentrations decline with age in model organisms (e.g., yeast, mice) as well as in humans (Scalabrino and Ferioli, 1984; Eisenberg et al., 2009; Pucciarelli et al., 2012; Gupta et al., 2013). Polyamines, like spermidine, can have procarcinogenic properties. Increased concentrations caused by enhanced biosynthesis can be found in different cancer types (Nowotarski et al., 2013). In contrast, cardiovascular diseases in humans and cancer manifestation in mice can be delayed by spermidine (Madeo et al., 2018). Dietary spermidine protects mice and probably also humans from cardiac aging, by e.g., improving the diastolic function or left ventricular elasticity (Soda et al., 2012; Eisenberg et al., 2016).

A Streptomyces strain, isolated from C. uncialis, produces the cytostatic enediyne uncialamycin, which shows strong antibacterial activity against the human pathogens E. coli,
B. cepacia and S. aureus (Davies et al., 2005; Parrot et al., 2016). The same Streptomyces strain generates also the alkaloids Cladoniamides A-G that show toxicity against human breast cancer MCF-7 cells (Williams et al., 2008). Another Streptomyces strain produces the tetrapeptide lichostatinal that represents a cathepsin $\mathrm{K}$ inhibitor and is therefore of interest for the therapy of osteoporosis (Yasuda et al., 2005; Lavallée, 2011). Two other Streptomyces species producing novel cytotoxic compounds: chlorinated anthraquinonic angucycline (Motohashi et al., 2010) and aminocoumarines structurally closed to novobiocine (Cheenpracha et al., 2010) were isolated from lichen species. Furthermore, S. cyaneofuscatus synthesizes methacrylate derivates with cytotoxic effects (Parrot et al., 2016). Other isolates of this species also demonstrate with high potential to produce a variety of anthracycline family antitumor antibiotics daunorubicin, cosmomycin B, galtamycin B and the antifungal macrolactam maltophilin (Ando et al., 1985; Jakobi et al., 1996; Antal et al., 2005). Actinoplanes sp. ATCC55532 produces actinoplanic acids $\mathrm{A}$ and $\mathrm{B}$. The latter inhibits farnesyl protein transferase and the farnesylation of the oncogene protein Ras. Thus, it has a potential for the treatment of colorectal carcinoma, exocrine pancreatic carcinoma and myeloid leukemia (Singh et al., 1997). Beside the discovery of novel bioactive lead compounds, direct antagonistic effects of bacteria of the lichen microbiome can be used as biological plant protection by defending plants against fungal plant pathogens, e.g., Alternaria alternata or Phytophthora infestans (Grube et al., 2009, 2012; Gasser et al., 2011; Kim et al., 2013a, 2014).

Despite the production of small metabolites, lichen-associated bacteria also show other biotechnological potentials. Many of these bacteria have the potential to produce PHA biopolymers and show high antagonistic potential against plant pathogens, like A. alternata (Gasser et al., 2011; Kim et al., 2013b, 2014). This is also mentioned in section "Microbiome Acquisition and Shaping."

\section{CONCLUDING REMARKS}

The morphological structure of the lichen thallus may affect the organization of the symbiotic networking. Metaorganisms such as lichens consist of highly integrated partnerships reflecting the classical dual definitions of the lichen symbiosis, and less tightly integrated partners with auxiliary functions (associated microbiome) (Hyvärinen et al., 2002; Cornejo and Scheidegger, 2013). In order to fully understand the microbiome contribution to the lichen symbiosis from a metabolic perspective, metabolomics could inform about the modes of nutrient exchange between the participating organisms. A question not yet properly addressed is, for example, whether bacteria thriving on the polysaccharides of the lichen mycobionts actively secrete certain compounds, or whether material from degrading bacteria is passively reabsorbed by the mycobiont. Degrading of bacteria might be forced by oxidative bursts, a well-known phenomenon from lichens in response to rehydration following desiccation (Minibayeva and Beckett, 2001). Selective bacterial degradation through 
oxidative bursts recalls not only a similar way of nutrient acquisition described from the plant rhizosphere (PaungfooLonhienne et al., 2010), but could also exert selective pressure on the bacterial lichen colonizers, favoring species, which cope particularly well with oxidative stress. However, experiments like carbon isotope labeling and comparative physiological analysis between lichens with and without the bacterial microbiota are difficult to assess due to slow metabolism and high bacterial diversity. Additionally, variation in the structure of the lichen holobiont or histochemical variation of lichen extracellular matrix due to bacterial colonization should be incorporated in the analyses of the lichen symbiotic model. Correlations between the compositions of the bacterial microbiome, climatic changes and fungal/algal genotypes would reveal new insights into the functionality of the bacterial microbiome, its acquisition and influence on the lichen holobiont.

Certainly, more work is required to understand the complex interplay between lichens and their bacterial colonizers.

\section{REFERENCES}

Abedin, M., and King, N. (2010). Diverse evolutionary paths to cell adhesion. Tr. Cell Biol. 20, 734-742. doi: 10.1016/j.tcb.2010.08.002

Adams, D. G., Bergman, B., Nierzwicki-Bauer, S. A., Rai, A. N., and Schüßler, A. (2006). "Cyanobacterial-plant symbioses," in The Prokaryotes, A Handbook on the Biology of Bacteria: Symbiotic associations, biotechnology, applied microbiology, 3rd Edn, Vol. 1, eds M. Dworkin, S. Falkow, E. Rosenberg, K. H. Schleifer, and E. Stackebrandt (New York, NY: Springer), 331-363. doi: 10.1007/ 0-387-30741-9_14

Adir, N., Bar-Zvi, S., and Harris, D. (2019). The amazing phycobilisome. BBABioenergetics 2019, 002. doi: 10.1016/j.bbabio.2019.07.002

Aguiar-Pulido, V., Huang, W., Suarez-Ulloa, V., Cickovski, T., Mathee, K., and Narasimhan, G. (2016). Metagenomics, metatranscriptomics, and metabolomics approaches for microbiome analysis. Evol. Bioinform. 12:S1. doi: 10.4137/EBO.S36436

Alavi, P., Starcher, M., Zachow, C., Müller, H., and Berg, G. (2013). Root-microbe systems: the effect and mode of interaction of stress protecting agent (SPA) Stenotrophomonas rhizophila DSM14405 ${ }^{T}$. Front. Plant Sci. 4:141. doi: 10.3389/ fpls.2013.00141

Almendras, K., García, J., Carú, M., and Orlando, J. (2018). Nitrogen-fixing bacteria associated with Peltigera cyanolichens and Cladonia chlorolichens. Molecules 23:3077. doi: 10.3390/molecules23123077

Al-Whaibi, M. H., Siddiqui, M. H., Sakran, A. M., Ali, H. M., and Basalah, M. O. (2012). Influence of plant growth regulators on growth performance and photosynthetic pigments status of Eruca sativa Mill. J. Med. Plants Res. 6, 1948-1954.

Amann, R. I., Ludwig, W., and Schleifer, K. H. (1995). Phylogenetic identification and in situ detection of individual microbial cells without cultivation. Microbiol. Rev. 59, 143-169. doi: 10.1128/mmbr.59.1.143-169.1995

Ando, T., Hirayama, K., Takahashi, R., Horino, I., Etoh, Y., Morioka, H., et al. (1985). The structures of anthracycline antibiotics, cosmomycins A and B. Agric. Biol. Chem. 49, 1207-1209. doi: 10.1271/bbb1961.49.1207

Antal, N., Fiedler, H. P., Stackebrandt, E., Beil, W., Ströch, K., and Zeeck, A. (2005). Retymicin, galtamycin B, saquayamycin $\mathrm{Z}$ and ribofuranosyllumichrome. Novel Secondary Metabolites from Micromonospora sp. Tü 6368. J. Antibiot. 58, 95-102. doi: 10.1038/ja.2005.12

Antoine, M. E., and McCune, B. (2004). Contrasting fundamental and realized ecological niches with epiphytic lichen transplants in an old-growth Pseudotsuga forest. Bryologist 107, 163-172. doi: 10.1639/0007-2745(2004) 107[0163:cfaren]2.0.co;2

Aptroot, A., and Alstrup, V. (1999). Three hyphomycetes isolated from the necrotic lichen Cladonia rangiformis. Cryptogam. Mycol. 20, 189-191. doi: 10.1016/ s0181-1584(00)87028-1

\section{AUTHOR CONTRIBUTIONS}

All authors contributed to the writing of the manuscript. MGru, $\mathrm{JB}$, and US created the figures.

\section{FUNDING}

The German Research Foundation (DFG) (GRK 2010) funded this work.

\section{ACKNOWLEDGMENTS}

KR acknowledges support by the German Research Foundation (DFG) funding the Research Training Group RESPONSE (GRK 2010). MGru acknowledges support by Field of Excellence "Complexity of Life in Basic Research and Innovation (COLIBRI)" at UNI Graz.

Aptroot, A., Van Herk, C. M., and Sparrius, L. B. (2012). Basisrapport voor de Rode Lijst korstmossen. Buxbaumiella 92, 1-117.

Aschenbrenner, I. A., Cardinale, M., Berg, G., and Grube, M. (2014). Microbial cargo: do bacteria on symbiotic propagules reinforce the microbiome of lichens? Environ. Microbiol. 16, 3743-3752. doi: 10.1111/1462-2920.12658

Aschenbrenner, I. A., Cernava, T., Berg, G., and Grube, M. (2016). Understanding microbial multi-species symbioses. Front. Microbiol. 7:180. doi: 10.3389/fmicb. 2016.00180

Aschenbrenner, I. A., Cernava, T., Erlacher, A., Berg, G., and Grube, M. (2017). Differential sharing and distinct co-occurrence networks among spatially close bacterial microbiota of bark, mosses and lichens. Mol. Ecol. 26, 2826-2838. doi: $10.1111 /$ mec. 14070

Asplund, J., Siegenthaler, A., and Gauslaa, Y. (2017). Simulated global warming increases usnic acid but reduces perlatolic acid in the mat-forming terricolous lichen Cladonia stellaris. Lichenologist 49, 269-274. doi: 10.1017/ s0024282917000159

Asta, J., Orry, F., Toutain, F., Souchier, B., and Villemin, G. (2001). Micromorphological and ultrastructural investigations of the lichen-soil interface. Soil Biol. Biochem. 33, 323-337. doi: 10.1016/s0038-0717(00)00143-7

Aubert, S., Juge, C., Boisson, A. M., Gout, E., and Bligny, R. (2007). Metabolic processes sustaining the reviviscence of lichen Xanthoria elegans (Link) in high mountain environments. Planta 226, 1287-1297. doi: 10.1007/s00425-0070563-6

Bardunov, L. V., and Novikov, V. S. (2008). Red Data Book of the Russian Federation (plants and fungi). Moscow: KMK Scientific Press Ltd.

Barták, M., Solhaug, K. A., Vráblíková, H., and Gauslaa, Y. (2006). Curling during desiccation protects the foliose lichen Lobaria pulmonaria against photoinhibition. Oecol. 149, 553-560. doi: 10.1007/s00442-006-0476-2

Bates, S. T., Cropsey, G. W., Caporaso, J. G., Knight, R., and Fierer, N. (2011). Bacterial communities associated with the lichen symbiosis. Appl. Environ. Microbiol. 77, 1309-1314. doi: 10.1128/aem.02257-10

Beckett, R. P., Minibayeva, F. V., Vylegzhanina, N. N., and Tolpysheva, T. (2003). High rates of extracellular superoxide production by lichens in the suborder Peltigerineae correlate with indices of high metabolic activity. Plant, Cell Env. 26, 1827-1837. doi: 10.1046/j.1365-3040.2003.01099.x

Berg, G., and Hallmann, J. (2006). "“Control of plant pathogenic fungi with bacterial endophytes,", in Microbial root endophytes, eds B. J. E. Schulz, C. J. C. Boyle, and T. N. Sieber (Berlin: Springer-Verlag), 53-69. doi: 10.1007/3-54033526-9_4

Berg, G., Bragina, A., Cardinale, M., Zachow, C., Müller, H., Berg, C., et al. (2011). From metagenome and proteome to biocontrol: analysis of moss-and lichen-associated microbial communities. IOBC/WPRS Bulletin 71, 13-16.

Bewley, J. D., and Krochko, J. E. (1982). "Desiccation-tolerance," in Physiological Plant Ecology II. Encyclopedia of Plant Physiology (New Series), Vol. 12 / B, eds 
O. L. Lange, P. S. Nobel, C. B. Osmond, and H. Ziegler (Berlin: Springer-Verlag), 325-378.

Bjelland, T., Grube, M., Hoem, S., Jorgensen, S. L., Daae, F. L., Thorseth, I. H., et al. (2011). Microbial metacommunities in the lichen-rock habitat. Environ. Microbiol. Rep. 3, 434-442. doi: 10.1111/j.1758-2229.2010. 00206.x

Blaha, J., Baloch, E., and Grube, M. (2006). High photobiont diversity associated with the euryoecious lichen-forming ascomycte Lecanora rupicola (Lecanoraceae. Ascomycota). Biol. J. Linn. Soc. 88, 283-293. doi: 10.1111/j. 1095-8312.2006.00640.x

Boucher, V. L., and Stone, D. E. (1992). "Epiphytic lichen biomass," in The fungal community: Its organization and role in the ecosystem, Second edition, eds G. C. Carroll and D. T. Wicklow (New York, NY: Marcell Dekker), 583-599.

Boustie, J., and Grube, M. (2005). Lichens - a promising source of bioactive secondary metabolites. Plant Gen. Res. 3, 273-287. doi: 10.1079/pgr200572

Bowler, P. A., and Rundel, P. W. (1975). Reproductive strategies in lichens. Bot. J. Linn. Soc. 70, 325-340. doi: 10.1111/j.1095-8339.1975.tb01653.x

Bradford, M. A., Davies, C. A., Frey, S. D., Maddox, T. R., Melillo, J. M., Mohan, J. E., et al. (2008). Thermal adaptation of soil microbial respiration to elevated temperature. Ecol. Let. 11, 1316-1327. doi: 10.1111/j.1461-0248.2008.01251.x

Brown, D. H., Rapsch, S., Beckett, A., and Ascaso, C. (1987). The effect of desiccation on cell shape in the lichen Parmelia sulcata Taylor. N. Phytol. 105, 295-299. doi: 10.1111/j.1469-8137.1987.tb00867.x

Brown, L. M., and Hellebust, J. A. (1978). Sorbitol and proline as intracellular osmotic solutes in the green alga Stichococcus bacillaris. Can. J. Bot. 56, 676-679. doi: $10.1139 / \mathrm{b} 78-074$

Büdel, B., and Scheidegger, C. (1996). "Thallus morphology and anatomy," in Lichen biology 2, ed. T. H. Nash III (Cambridge, UK: Cambridge University, Press)), 40-68. doi: 10.1017/cbo9780511790478.005

Burkholder, P. R., Evans, A. W., McVeigh, I., and Thornton, H. K. (1944). Antibiotic activity of lichens. Proc. Natl. Acad Sci. U.S.A. 30, 250-255. doi: 10.1073/pnas.30.9.250

Calcott, M. J., Ackerley, D. F., Knight, A., Keyzers, R. A., and Owen, J. G. (2018). Secondary metabolism in the lichen symbiosis. Chem. Soc. Rev. 47, 1730-1760. doi: $10.1039 / \mathrm{C} 7 \mathrm{CS} 00431 \mathrm{~A}$

Campbell, J., Bengtson, P., Fredeen, A. L., Coxson, D. S., and Prescott, C. E. (2013). Does exogenous carbon extend the realized niche of canopy lichens? Evidence from sub-boreal forests in British Columbia. Ecology 94, 1186-1195. doi: $10.1890 / 12-1857.1$

Carbonero, E. R., Cordeiro, L. M., Mellinger, C. G., Sassaki, G. L., StockerWörgötter, E., Gorin, P. A., et al. (2005). Galactomannans with novel structures from the lichen Roccella decipiens Darb. Carbohydrate Res. 340, 1699-1705. doi: 10.1016/j.carres.2005.03.022

Cardarelli, M., Serino, G., Campanella, L., Ercole, P., Nardone, F. D. C., Alesiani, O., et al. (1997). Antimitotic effects of usnic acid on different biological systems. Cel. Mol. Life Sci. 53, 667-672. doi: 10.1007/s000180050086

Cardinale, B. J., Palmer, M. A., Swan, C. M., Brooks, S., and Poff, N. L. (2002). The influence of substrate heterogeneity on biofilm metabolism in a stream ecosystem. Ecology 83, 412-422. doi: 10.1890/0012-9658(2002)083[0412: tiosho]2.0.co;2

Cardinale, M., Grube, M., Castro, Jr., Müller, H., and Berg, G. (2012a). Bacterial taxa associated with the lung lichen Lobaria pulmonaria are differentially shaped by geography and habitat. FEMS Microbiol. Lett. 329, 111-115. doi: 10.1111/j.1574-6968.2012.02508.x

Cardinale, M., Puglia, A. M., and Grube, M. (2006). Molecular analysis of lichenassociated bacterial communities. FEMS Microbiol. Ecol. 57, 484-495. doi: 10.1111/j.1574-6941.2006.00133.x

Cardinale, M., Steinová, J., Rabensteiner, J., Berg, G., and Grube, M. (2012b). Age, sun and substrate: triggers of bacterial communities in lichens. Environ. Microbiol. Rep. 4, 23-28. doi: 10.1111/j.1758-2229.2011.00272.x

Cardinale, M., Vieira, de Castro, Jr., Müller, H., Berg, G., and Grube, M. (2008). In situ analysis of the bacterial community associated with the reindeer lichen Cladonia arbuscula reveals predominance of Alphaproteobacteria. FEMS Microbiol. Ecol. 66, 63-71. doi: 10.1111/j.15746941.2008.00546.x

Cava, F., Lam, H., De Pedro, M. A., and Waldor, M. K. (2011). Emerging knowledge of regulatory roles of D-amino acids in bacteria. Cell. Mol. Life Sci. 68, 817-831. doi: 10.1007/s00018-010-0571-8
Cengia Sambo, M. (1926). Ancora della polysimbiosi nei licheni ad alghe cianoficee. 1. Batteri simbionti. Atti Soc. Ital. Sc. Nat. 64:5.

Centeno, D. C., Hell, A. F., Braga, M. R., Del Campo, E. M., and Casano, L. M. (2016). Contrasting strategies used by lichen microalgae to cope with desiccation-rehydration stress revealed by metabolite profiling and cell wall analysis. Environ. Microbiol. 18, 1546-1560. doi: 10.1111/1462-2920.13249

Cernava, T., Aschenbrenner, I. A., Soh, J., Sensen, C. W., Grube, M., and Berg, G. (2019). Plasticity of a holobiont: desiccation induces fasting-like metabolism within the lichen microbiota. ISME J. 13, 547-556. doi: 10.1038/s41396-0180286-7

Cernava, T., Erlacher, A., Aschenbrenner, I. A., Krug, L., Lassek, C., Riedel, K., et al. (2017). Deciphering functional diversification within the lichen microbiota by meta-omics. Microbiome 5:82. doi: 10.1186/s40168-017-0303-5

Cernava, T., Müller, H., Aschenbrenner, I. A., Grube, M., and Berg, G. (2015). Analyzing the antagonistic potential of the lichen microbiome against pathogens by bridging metagenomic with culture studies. Front. Microbiol. 6:620. doi: $10.3389 /$ fmicb.2015.00620

Cernava, T., Vasfiu, Q., Erlacher, A., Aschenbrenner, I. A., Francesconi, K., Grube, M., et al. (2018). Adaptions of lichen microbiota functioning under persistent exposure to arsenic contamination. Front. Microbiol. 9:02959. doi: 10.3389/ fmicb.2018.02959

Cheenpracha, S., Vidor, N. B., Yoshida, W. Y., Davies, J., and Chang, L. C. (2010). Coumabiocins A-F aminocoumarins from an organic extract of Streptomyces sp. J. Nat. Prod. 73, 880-884. doi: 10.1021/np900843b

Chen, Y., Yu, L., Liu, F., and Du, L. (2018). Spermidine-regulated biosynthesis of heat-stable antifungal factor (HSAF) in Lysobacter enzymogenes OH11. Front. Microbiol. 9:2984. doi: 10.3389/fmicb.2018.02984

Cordeiro, L. M., Beilke, F., de Fátima Reinhardt, V., Sassaki, G. L., and Iacomini, M. (2013). Rhamnogalactofuranan from the microalga Myrmecia biatorellae, symbiotic partner of Lobaria linita. Phytochemistry 94, 254-259. doi: 10.1016/ j.phytochem.2013.06.008

Cordeiro, L. M., Carbonero, E. R., Sassaki, G. L., Reis, R. A., Stocker-Wörgötter, E., Gorin, P. A., et al. (2005). A fungus-type $\beta$-galactofuranan in the cultivated Trebouxia photobiont of the lichen Ramalina gracilis. FEMS Microbiol. Lett. 244, 193-198.

Cordeiro, L. M., de Oliveira, S. M., Buchi, D. F., and Iacomini, M. (2008). Galactofuranose-rich heteropolysaccharide from Trebouxia sp., photobiont of the lichen Ramalina gracilis and its effect on macrophage activation. In. J. Biol. Macromol. 42, 436-440. doi: 10.1016/j.ijbiomac.2008.02.002

Cordeiro, L. M., Sassaki, G. L., Gorin, P. A., and Iacomini, M. (2010). O-Methylated mannogalactan from the microalga Coccomyxa mucigena, symbiotic partner of the lichenized fungus Peltigera aphthosa. Phytochemistry 71, 1162-1167. doi: 10.1016/j.phytochem.2010.04.004

Cordeiro, L. M., Stocker-Wörgötter, E., Gorin, P. A., and Iacomini, M. (2003). Comparative studies of the polysaccharides from species of the genus Ramalina-lichenized fungi-of three distinct habitats. Phytochemistry 63, 967975. doi: 10.1016/s0031-9422(03)00336-4

Cornejo, C., and Scheidegger, C. (2013). New morphological aspects of cephalodium formation in the lichen Lobaria pulmonaria (Lecanorales. Ascomycota). Lichenologist 45, 77-87. doi: 10.1017/s0024282912000631

Cornejo, C., Nelson, P. R., Stepanchikova, I., Himelbrant, D., Jørgensen, P. M., and Scheidegger, C. (2005). Contrasting pattern of photobiont diversity in the Atlantic and Pacific populations of Erioderma pedicellatum (Pannariaceae). Lichenologist 48, 275-291. doi: 10.1017/s0024282916000311

Cornett, D. S., Reyzer, M. L., Chaurand, P., and Caprioli, R. M. (2007). MALDI imaging mass spectrometry: molecular snapshots of biochemical systems. Nat. Methods 4, 828-833. doi: 10.1038/nmeth1094

Coxson, D. S., and Nadkarni, N. M. (1995). "Ecological Roles of Epiphytes in Nutrient Cycles of Forest Ecosystem," in Forest Canopies, eds M. D. Lowman and N. M. Nadkarni (SanDiego, USA: Academic Press), 495-543.

Croft, M. T., Lawrence, A. D., Raux-Deery, E., Warren, M. J., and Smith, A. G. (2005). Algae acquire vitamin B 12 through a symbiotic relationship with bacteria. Nature 438, 90-93. doi: 10.1038/nature04056

Crowther, T. W., and Bradford, M. A. (2013). Thermal acclimation in widespread heterotrophic soil microbes. Ecol. Lett. 16, 469-477. doi: 10.1111/ele.12069

Darnajoux, R., Zhang, X., McRose, D. L., Miadlikowska, J., Lutzoni, F., Kraepiel, A. M., et al. (2017). Biological nitrogen fixation by alternative nitrogenases in boreal cyanolichens: importance of molybdenum availability and implications 
for current biological nitrogen fixation estimates. N. Phytol. 213, 680-689. doi: $10.1111 / \mathrm{nph} .14166$

Davies, J. E., Waters, B., and Saxena, G. (2002). Method for inhibiting eukaryotic protein kinases. U.S. Patent No. 6,455,270. Washington, DC: U.S. Patent and Trademark Office.

Davies, J., Wang, H., Taylor, T., Warabi, K., Huang, X. H., and Andersen, R. J. (2005). Uncialamycin, a new enediyne antibiotic. Org. Lett. 7, 5233-5236. doi: $10.1021 / \mathrm{ol} 052081 \mathrm{f}$

De Baets, S., and Vandamme, E. J. (2001). Extracellular Tremella polysaccharides: structure, properties and applications. Biotechnol. Lett. 23, 1361-1366.

De Los Rios, A., and Grube, M. (2000). Host parasite interfaces of some lichenicolous fungi in the Dacampiaceae (Dothideales, Ascomycota). Mycol. Res. 104, 1348-1353. doi: 10.1017/s0953756200002951

Demmig-Adams, B., Máguas, C., Adams, W. W., Meyer, A., Kilian, E., and Lange, O. L. (1990). Effect of high light on the efficiency of photochemical energy conversion in a variety of lichen species with green and blue-green phycobionts. Planta 180, 400-409. doi: 10.1007/bf01160396

Didehdar, M., Gokanian, A., Sofian, M., Mohammadi, S., Mohammadi, R., Aslani, N., et al. (2015). First fatal cerebral phaeohyphomycosis due to Rhinocladiella mackenziei in Iran, based on ITS rDNA. J. Mycol. Medicale 25, 81-86. doi: 10.1016/j.mycmed.2014.11.003

Diederich, P., Lawrey, J. D., and Ertz, D. (2018). The 2018 classification and checklist of lichenicolous fungi, with 2000 non-lichenized, obligately lichenicolous taxa. Bryologist 121, 340-425. doi: 10.1639/0007-2745-121.3.340

Doering, M., and Coxson, D. (2010). Riparian alder ecosystems as epiphytic lichen refugia in sub-boreal spruce forests of British Columbia. Botany 88, 144-157. doi: 10.1139/b09-096

Dudley, S. A., and Lechowicz, M. J. (1987). Losses of polyol through leaching in subarctic lichens. Plant Physiol. 83, 813-815. doi: 10.1104/pp.83.4.813

Eaton, S., and Ellis, C. J. (2014). High demographic rates of the model epiphyte Lobaria pulmonaria in an oceanic hazelwood (western Scotland). Fung. Ecol. 11, 60-70. doi: 10.1016/j.funeco.2014.03.007

Edman, M., Eriksson, A. M., and Villard, M. A. (2008). Effects of selection cutting on the abundance and fertility of indicator lichens Lobaria pulmonaria and L. quercizans. J. Appl. Ecol. 45, 26-33. doi: 10.1111/j.1365-2664.2007.01354.x

Eisenberg, T., Abdellatif, M., Schroeder, S., Primessnig, U., Stekovic, S., Pendl, T., et al. (2016). Cardioprotection and lifespan extension by the natural polyamine spermidine. Nat. Med. 22:1428.

Eisenberg, T., Knauer, H., Schauer, A., Büttner, S., Ruckenstuhl, C., CarmonaGutierrez, D., et al. (2009). Induction of autophagy by spermidine promotes longevity. Nat. Cell Biol. 11, 1305-1314.

Eisenreich, W., Knispel, N., and Beck, A. (2011). Advanced methods for the study of the chemistry and the metabolism of lichens. Phytochem. Rev. 10, 445-456. doi: 10.1007/s11101-011-9215-3

Elix, J. A., and Stocker-Wörgötter, E. (1996). "“Biochemistry and secondary metabolites,", in Lichen biology, Cambridge, ed. T. H. Nash III (UK: Cambridge University Press), 154-180.

Ellis, C. J., Crittenden, P. D., Scrimgeour, C. M., and Ashcroft, C. J. (2005). Translocation of ${ }^{15} \mathrm{~N}$ indicates nitrogen recycling in the mat-forming lichen Cladonia portentosa. N. Phytol. 168, 423-434. doi: 10.1111/j.1469-8137.2005. 01524.x

Erlacher, A., Cernava, T., Cardinale, M., Soh, J., Sensen, C. W., Grube, M., et al. (2015). Rhizobiales as functional and endosymbiontic members in the lichen symbiosis of Lobaria pulmonaria L. Front. Microbiol. 6:53. doi: 10.3389/fmicb. 2015.00053

Eymann, C., Lassek, C., Wegner, U., Bernhardt, J., Fritsch, O. A., Fuchs, S., et al. (2017). Symbiotic interplay of fungi, algae, and bacteria within the lung lichen Lobaria pulmonaria L. Hoffm. as Assessed by State-of-the-Art Metaproteomics. J. Proteome Res. 16, 2160-2173. doi: 10.1021/acs.jproteome.6b00974

Farkas, E., and Lõkös, L. (2009). Lobaria pulmonaria (lichen-forming fungi) in Hungary. Mikológiai Közlemények, Clusiana 48, 11-18.

Farmer, A. M., Bates, J. W., and Bell, J. N. B. (1991). Comparisons of three woodland sites in NW Britain differing in richness of the epiphytic Lobarionpulmonariae community and levels of wet acidic deposition. Holarct. Ecol. 19, 85-91. doi: 10.1111/j.1600-0587.1991.tb00637.x

Farrar, J. F. (1988). "Physiological buffering," in Handbook of Lichenology, Vol. 11, ed. M. Galun (Boca Raton, FL: CRC Press), 101-105.
Fernandéz-Mendoza, F., Fleischhacker, A., Kopun, T., Grube, M., and Muggia, L. (2017). ITS1 metabarcoding highlights low specificity of lichen mycobiomes at a local scale. Mol. Ecol. 26, 4811-4830. doi: 10.1111/mec.14244

Fiechter, E. (1990). Thallusdifferenzierung und intrathalline Sekundärstoffverteilung bei Parmeliaceae (Lecanorales, lichenisierte Ascomyceten). doctoral dissertation, Zürich (Switzerland)]: Universität Zürich.

Francolini, I., Norris, P., Piozzi, A., Donelli, G., and Stoodley, P. (2004). Usnic acid, a natural antimicrobial agent able to inhibit bacterial biofilm formation on polymer surfaces. Antimicrob. Agents Chemoth. 48, 4360-4365. doi: 10.1128/ aac.48.11.4360-4365.2004

Garg, N., Zeng, Y., Edlund, A., Melnik, A. V., Sanchez, L. M., Mohimani, H., et al. (2016). Spatial molecular architecture of the microbial community of a Peltigera lichen. Nov. Syst. Biol. Tech. 1:6. doi: 10.1128/mSystems.00139-16

Garty, J. (2001). Biomonitoring atmospheric heavy metals with lichens: theory and application. Crit. Rev. Plant Sci. 20, 309-371. doi: 10.1016/s0735-2689(01) 80040- $\mathrm{x}$

Gasser, I., Cardinale, M., Müller, H., Heller, S., Eberl, L., Lindenkamp, N., et al. (2011). Analysis of the endophytic lifestyle and plant growth promotion of Burkholderia terricola ZR2-12. Plant Soil 347, 125-136. doi: 10.1007/s11104011-0833-8

Gauslaa, Y., and McEvoy, M. (2005). Seasonal changes in solar radiation drive acclimation of the sun-screening compound parietin in the lichen Xanthoria parietina. Basic Appl. Ecol. 6, 75-82. doi: 10.1016/j.baae.2004.10.003

Gauslaa, Y., and Solhaug, K. A. (1996). Differences in the susceptibility to light stress between epiphytic lichens of ancient and young boreal forest stands. Funct. Ecol. 10, 344-354. doi: 10.2307/2390282

Gauslaa, Y., and Solhaug, K. A. (1999). High-light damage in air-dry thalli of the old forest lichen Lobaria pulmonaria - interactions of irradiance, exposure duration and high temperature. J. Exp. Bot. 50, 697-705. doi: 10.1093/jexbot/ 50.334 .697

Gauslaa, Y., and Solhaug, K. A. (2000). High-light-intensity damage to the foliose lichen Lobaria pulmonaria within natural forest: the applicability of chlorophyll fluorescence methods. Lichenologist 32, 271-289. doi: 10.1006/lich.1999.0265

Gauslaa, Y., and Solhaug, K. A. (2001). Fungal melanins as a sun screen for symbiotic green algae in the lichen Lobaria pulmonaria. Oecol. 126, 462-471. doi: 10.1007/s004420000541

Germerodt, S., Bohl, K., Lück, A., Pande, S., Schröter, A., Kaleta, C., et al. (2016). Pervasive selection for cooperative cross-feeding in bacterial communities. PLoS Comput. Biol. 12:6. doi: 10.1371/journal.pcbi.1004986

Gianini, A. S., Marques, M. R., Carvalho, N. C. P., and Honda, N. K. (2008). Activities of 2,4-Dihydroxy-6-n-pentylbenzoic Acid Derivates. Z. Naturf. 63, 29-34. doi: 10.1515/znc-2008-1-206

González, I., Ayuso-Sacido, A., Anderson, A., and Genilloud, O. (2005). Actinomycetes isolated from lichens: evaluation of their diversity and detection of biosynthetic gene sequences. FEMS Microbiol. Ecol. 54, 401-415. doi: 10 . 1016/j.femsec.2005.05.004

Gorin, P. A. J., and Barreto-Bergter, E. (1983). "The chemistry of polysaccharides of fungi and lichens," in The Polysaccharides, Vol. 2, ed. F. O. Aspinall (New York: Academic Press), 365-409. doi: 10.1016/b978-0-12-065602-8.50011-x

Graham, L. E., Trest, M. T., Will-Wolf, S., Miicke, N. S., Atonio, L. M., Piotrowski, M. J., et al. (2018). Microscopic and metagenomic analyses of Peltigera ponojensis (Peltigerales, Ascomycota). Int. J. Plant Sci. 179, 241-255. doi: 10. $1086 / 696534$

Grube, M. (2018). The lichen thallus as a microbial habitat. Biosyst. Ecol. Ser. 34, $528-545$.

Grube, M., and Berg, G. (2009). Microbial consortia of bacteria and fungi with focus on the lichen symbiosis. Fung. Biol. Rev. 23, 72-85. doi: 10.1016/j.fbr. 2009.10.001

Grube, M., and De Los Rios, A. (2001). Observations in Biatoropsis usnearum and other gall forming lichenicolous fungi using different microscopic techniques. Mycol. Res. 105, 1116-1122. doi: 10.1016/s0953-7562(08)61975-9

Grube, M., and Hafellner, J. (1990). Studien an flechtenbewohnenden Pilzen der Sammelgattung Didymella (Ascomycetes, Dothideales). Nova Hedwigia 51, 283-360.

Grube, M., and Hawksworth, D. L. (2007). Trouble with lichen: the re-evaluation and re-interpretation of thallus form and fruit body types in the molecular era. Mycol. Res. 111, 1116-1132. doi: 10.1016/j.mycres.2007.04.008 
Grube, M., Cardinale, M., de Castro, J. V., Müller, H., and Berg, G. (2009). Speciesspecific structural and functional diversity of bacterial communities in lichen symbioses. ISME J. 3, 1105-1115. doi: 10.1038/ismej.2009.63

Grube, M., Cardinale, M., de Castro, J. V., Müller, H., and Berg, G. (2012). Hostparasite interaction and microbiome response: effects of fungal infections on the bacterial community of the Alpine lichen Solorina crocea. FEMS Microbiol. Ecol. 82, 472-481. doi: 10.1111/j.1574-6941.2012.01425.x

Grube, M., Cernava, T., Soh, J., Fuchs, S., Aschenbrenner, I., Lassek, C., et al. (2015). Exploring functional contexts of symbiotic sustain within lichen-associated bacteria by comparative omics. ISME J. 9, 412-424. doi: 10.1038/ismej.2014.138

Gupta, V. K., Scheunemann, L., Eisenberg, T., Mertel, S., Bhukel, A., Koemans, T. S., et al. (2013). Restoring polyamines protects from age-induced memory impairment in an autophagy-dependent manner. Nat. Neurosci. 16, 1453-1460. doi: $10.1038 / \mathrm{nn} .3512$

Hakulinen, R. (1964). Die Flechtengattung Lobaria Schreb. in Ostfennoskandien. Ann. Bot. Fen. 1, 202-213.

Hallingbäck, T., and Martinsson, P.-O. (1987). The retreat of two lichens, Lobaria pulmonaria and L. scrobiculata in the district of Gäsene (SW Sweden). Windahlia 17, 27-32. doi: 10.14492/hokmj/1381758488

Hallingback, T., and Olsson, K. (1987). Lunglavens tillbakagang i Skane. Sv. Bot. Tidskr. 81, 103-108.

Hassa, J., Maus, I., Off, S., Pühler, A., Scherer, P., Klocke, M., et al. (2018). Metagenome, metatranscriptome, and metaproteome approaches unraveled compositions and functional relationships of microbial communities residing in biogas plants. Appl. Microbiol. Biotechnol. 102, 5045-5063. doi: 10.1007/ s00253-018-8976-7

Hauck, M., and Wirth, V. (2010). Preference of lichens for shady habitats is correlated with intolerance to high nitrogen levels. Lichenologist 42, 475-484. doi: 10.1017/s0024282910000046

Hauck, M., Jürgens, S. R., Brinkmann, M., and Herminghaus, S. (2008). Surface hydrophobicity causes SO2 tolerance in lichens. Ann. Bot. 101, 531-539. doi: $10.1093 / \mathrm{aob} / \mathrm{mcm} 306$

Hawksworth, D. L., and Grube, M. (2020). Lichens redefined as complex ecosystems. N. Phytol. 227, 1281-1283. doi: 10.1111/nph.16630

Hawksworth, D. L., and Hill, D. J. (1984). The lichen-forming fungi. Glasgow \& London: Blackie.

Hawksworth, D. L., and Rose, F. (1970). Qualitative scale for estimating sulphur dioxide air pollution in England and Wales using epiphytic lichens. Nature 227, 145-148. doi: 10.1038/227145a0

Hawksworth, D. L., Kirk, P. M., Sutton, B. C., and Pegler, D. N. (1995). Dictionary of the Fungi, 8th Edn. Wallingford: CAB International.

Hawksworth, D. L., Rose, F., and Coppins, B. J. (1973). "Changes in the lichen flora of England and Wales attributable to pollution of the air by sulphur dioxide," in Air Pollution and Lichens, eds B. W. Ferry, M. S. Baddeley, and D. L. Hawksworth (London: Athlone Press), 330-367.

Heber, U., Bilger, W., Türk, R., and Lange, O. L. (2010). Photoprotection of reaction centres in photosynthetic organisms: mechanisms of thermal energy dissipation in desiccated thalli of the lichen Lobaria pulmonaria. N. Phytol. 185, 459-470. doi: 10.1111/j.1469-8137.2009.03064.x

Henckel, P. A., and Yuzhakova, L. A. (1936). On the role of Azotobacter in the lichen symbiosis. Bull. Perm Biol. Res. Inst. 10:315.

Henkel, P. A., and Plotnikova, T. T. (1973). Nitrogen-fixing bacteria in lichens. Izv. Akad. Nauk. Ser. Biol. 1973, 807-813.

Heyer, R., Schallert, K., Zoun, R., Becher, B., Saake, G., and Benndorf, D. (2017). Challenges and perspectives of metaproteomic data analysis. J. Biotech. 261, 24-36. doi: 10.1016/j.jbiotec.2017.06.1201

Hill, D. J. (1972). The movement of carbohydrate from the alga to the fungus in the lichen Peltigera polydactyla. N. Phytol. 71, 31-39. doi: 10.1111/j.1469-8137. 1972.tb04807.x

Hill, D. J. (1976). “The physiology of lichen symbiosis,” in Lichenology: Progress and Problems, eds D. H. Brown, D. L. Hawksworth, and R. H. Bailey (San Francisco: Academic Press), 457-496.

Hodkinson, B. P., and Lutzoni, F. (2009). A microbiotic survey of lichen-associated bacteria reveals a new lineage from the Rhizobiales. Symbiosis 49, 163-180. doi: 10.1007/s13199-009-0049-3

Hodkinson, B. P., Gottel, N. R., Schadt, C. W., and Lutzoni, F. (2012). Photoautotrophic symbiont and geography are major factors affecting highly structured and diverse bacterial communities in the lichen microbiome. Environ. Microbiol. 14, 147-161. doi: 10.1111/j.1462-2920.2011.02560.x
Honegger, R. (1984). Cytological aspects of the mycobiont-phycobiont relationship in lichens: haustorial types, phycobiont cell wall types, and the ultrastructure of the cell surface layers in some cultured and symbiotic myco-and phycobionts. Lichenologist 16, 111-127. doi: $10.1017 / \mathrm{s} 0024282984000293$

Honegger, R. (1987). Questions about pattern formation in the algal layer of lichens with stratified (heteromerous) thalli. Biblioth. Lichenol. 25, 59-71.

Honegger, R. (1990). "Surface interactions in lichens," in Experimental Phycology Vol. 1: Cell Walls and Surfaces, Reproduction, Photosynthesis, eds W. Wiessner, D. G. Robinson, and R. C. Starr (Berlin: Springer-Verlag), 40-54. doi: 10.1007/ 978-3-642-48652-4_3

Honegger, R. (1991). Functional aspects of the lichen symbiosis. Annu. Rev. Plant Physiol. Plant Mol. Biol. 42, 553-578. doi: 10.1146/annurev.pp.42.060191. 003005

Honegger, R. (1993). Tansley Review No. 60: Developmental biology of lichens. N. Phytol. 125, 659-677. doi: 10.1111/j.1469-8137.1993.tb03916.x

Honegger, R. (1996). “"Morphogenesis,”” in Lichen biology, ed. T. H. Nash III (Cambridge, UK: Cambridge University Press), 65-87.

Honegger, R. (1997). "Metabolic interactions at the mycobiont-photobiont interface in lichens," in The Mycota: Plant relationships Part A, eds G. C. Carroll and P. Tudzynski (Berlin: Springer-Verlag), 209-221. doi: 10.1007/978-3-66210370-8_12

Honegger, R., Edwards, D., and Axe, L. (2013). The earliest records of internally stratified cyanobacterial and algal lichens from the Lower Devonian of the Welsh Borderland. N. Phytol. 197, 264-275. doi: 10.1111/nph.12009

Hrouzek, P. (2017). "Secondary metabolites produced by cyanobacteria in symbiotic associations," in Algal and cyanobacteria symbioses, eds M. Grube, J. Seckbach, and L. Muggia (Singapore: World Scientific), 611-626. doi: 10.1142/ 9781786340580_0019

Hunter, P. (2006). Entente cordiale. EMBO Rep. 7, 861-864.

Hyvärinen, M., Härdling, R., and Tuomi, J. (2002). Cyanobacterial lichen symbiosis: the fungal partner as an optimal harvester. Oikos 98, 498-504. doi: 10.1034/j.1600-0706.2002.980314.x

Ingólfsdóttir, K., Chung, G. A., Skúlason, V. G., Gissurarson, S. R., and Vilhelmsdóttir, M. (1998). Antimycobacterial activity of lichen metabolites in vitro. Europ. J. Pharma. Sci. 6, 141-144. doi: 10.1016/s0928-0987(97)00078-x

Iskina, R. Y. (1938). On nitrogen fixing bacteria in lichens. Isv. Biol. Inst. Permsk. 11, 133-139.

Jabeen, K., Farooqi, J., Zafar, A., Jamil, B., Faisal Mahmood, S., Ali, F., et al. (2011). Rhinocladiella mackenziei as an emerging cause of cerebral phaeohyphomycosis in Pakistan: a case series. Clin. Infect. Dis. 52, 213-217. doi: 10.1093/cid/ciq114

Jahns, H. M. (1988). “"The lichen thallus,", in CRC Handbook of Lichenology, Vol. 1, ed. M. Galun (Baca Raton, FL: CRC Press), 95-143. doi: 10.1201/ 9780429291784-4

Jakobi, M., Winkelmann, G., Kaiser, D., Kempter, C., Jung, G., Berg, G., et al. (1996). Maltophilin: A new antifungal compound produced by Stenotrophomonas maltophilia R3089. J. Antibiot. 49, 1101-1104. doi: 10.7164/antibiotics.49.1101

Jehmlich, N., Vogt, C., Lünsmann, V., Richnow, H. H., and von Bergen, M. (2016). Protein-SIP in environmental studies. Curr. Op. Biotechnol. 41, 26-33. doi: 10.1016/j.copbio.2016.04.010

Jennings, D. H., and Lysek, G. (1996). Fungal biology: understanding the fungal lifestyle. London: Bios Scientific Publishers Ltd.

Jordan, W. P. (1970). The internal cephalodia of the genus Lobaria. Bryologist 73, 669-681. doi: 10.2307/3241279

Jüriado, I., and Liira, J. (2009). Distribution and habitat ecology of the threatened forest lichen Lobaria pulmonaria in Estonia. Fol. Cryptog. Est. 46, 55-65.

Jüriado, I., Liira, J., Csencsics, D., Widmer, I., Adolf, C., Kohv, K., et al. (2011). Dispersal ecology of the endangered woodland lichen Lobaria pulmonaria in managed hemiboreal forest landscape. Biodiv. Conserv. 20, 1803-1819. doi: 10.1007/s10531-011-0062-8

Kaasalainen, U., Fewer, D. P., Jokela, J., Wahlsten, M., Sivonen, K., and Rikkinen, J. (2012). Cyanobacteria produce a high variety of hepatotoxic peptides in lichen symbiosis. Proc. Natl. Acad Sci. U.S.A 109, 5886-5891. doi: 10.1073/pnas. 1200279109

Kaasalainen, U., Jokela, J., Fewer, D. P., Sivonen, K., and Rikkinen, J. (2009). Microcystin production in the tripartite cyanolichen Peltigera leucophlebia. Mol. Plant-Microbe Interact. 22, 695-702. doi: 10.1094/mpmi-22-6-0695

Kadereit, J. W., Körner, C., Kost, B., and Sonnewald, U. (2014). StrasburgerLehrbuch der Pflanzenwissenschaften. Berlin: Springer-Verlag. 
Kalwij, J. M., Wagner, H. H., and Scheidegger, C. (2005). Effects of standlevel disturbance events on the spatial distribution of a lichen indicator of forest conservation value. Ecol. Appl. 15, 2015-2024. doi: 10.1890/041912

Karpievitch, Y. V., Polpitiya, A. D., Anderson, G. A., Smith, R. D., and Dabney, A. R. (2010). Liquid chromatography mass spectrometry-based proteomics: biological and technological aspects. Ann. Appl. Stat. 4:4. doi: 10.1214/10AOAS341

Kershaw, K. A. (1985). Physiological ecology of lichens. Cambridge: Cambridge University Press.

Kim, M. K., Oh, T. J., and Park, H. (2013b). Antimicrobial properties of the bacterial associates of the Arctic lichen Stereocaulon sp. Afr. J. Microbiol. Res. 7, 3651-3657.

Kim, M. K., Park, H., and Oh, T. J. (2013a). Antioxidant properties of various microorganisms isolated from arctic lichen Stereocaulon spp. Microbiol. Biotech. Lett. 41, 350-357. doi: 10.4014/kjmb.1303.03004

Kim, M. K., Park, H., and Oh, T. J. (2014). Antibacterial and antioxidant capacity of polar microorganisms isolated from Arctic lichen Ochrolechia sp. Pol. J. Microbiol. 63, 317-322. doi: 10.33073/pjm-2014-042

Kinoshita, K., Fukumaru, M., Yamamoto, Y., Koyama, K., and Takahashi, K. (2015). Biosynthesis of panaefluoroline B from the cultured mycobiont of Amygdalaria panaeola. J. Nat. Prod. 78, 1745-1747. doi: 10.1021/acs.jnatprod.5b00 055

Klarenberg, I. J., Keuschnig, C., Warshan, D., Jónsdóttir, I. S., and Vilhelmsson, O. (2020). The total and active bacterial community of the chlorolichen Cetraria islandica and its response to long-term warming in sub-Arctic tundra. Available online at: https://www.biorxiv.org/content/10.1101/2020.03. 04.976944v1.abstract (accessed August 11, 2020).

Kleiner, M. (2019). Metaproteomics: much more than measuring gene expression in microbial communities. mSystems 4:3. doi: 10.1128/mSystems. 00115- 19

Kleiner, M., Dong, X., Hinzke, T., Wippler, J., Thorson, E., Mayer, B., et al. (2018). Metaproteomics method to determine carbon sources and assimilation pathways of species in microbial communities. Proc. Natl. Acad. Sci. U.S.A. 115:24. doi: 10.1073/pnas.1722325115

Kolodkin-Gal, I., Romero, D., Cao, S., Clardy, J., Kolter, R., and Losick, R. (2010). D-amino acids trigger biofilm disassembly. Science 328, 627-629. doi: 10.1126/ science.1188628

Kopycińska, M., Lipa, P., Cieśla, J., Kozieł, M., and Janczarek, M. (2018). Extracellular polysaccharide protects Rhizobium leguminosarum cells against zinc stress in vitro and during symbiosis with clover. Environ. Microbiol. Rep. 10, 355-368. doi: 10.1111/1758-2229.12646

Kranner, I., Cram, W. J., Zorn, M., Wornik, S., Yoshimura, I., Stabentheiner, E., et al. (2005). Antioxidants and photoprotection in a lichen as compared to its isolated symbiotic partners. Proc. Natl. Acad. Sci. U.S.A. 102, 3141-3146. doi: 10.1073/pnas.0407716102

Kranner, I., Cram, W. J., Zorn, M., Wornik, S., Yoshimura, I., Stabentheiner, E., et al. (2008). Desiccation-tolerance in lichens: a review. Bryologist 111, 576-593. doi: 10.1639/0007-2745-111.4.576

Kuhn, V., Geisberger, T., Huber, C., Beck, A., and Eisenreich, W. (2019). A facile in vivo procedure to analyze metabolic pathways in intact lichens. N. Phytol 224, 1657-1667. doi: 10.1111/nph.15968

Kunath, B. J., Minniti, G., Skaugen, M., Hagen, L. H., Vaaje-Kolstad, G., Eijsink, V. G., et al. (2019). "'Metaproteomics: sample preparation and methodological considerations,", in Emerging Sample Treatments in Proteomics. Advances in Experimental Medicine and Biology, Vol. 1073, ed. J. L. Capelo-Martínez (Berlin: Springer), 187-215. doi: 10.1007/978-3-030-12298-0_8

Lam, H., Oh, D. C., Cava, F., Takacs, C. N., Clardy, J., de Pedro, M. A., et al. (2009). $\mathrm{D}$-amino acids govern stationary phase cell wall remodeling in bacteria. Science 325, 1552-1555. doi: 10.1126/science. 1178123

Larson, D. W. (1987). The absorption and release of water by lichens. Biblioth. Lichenol. 25, 1-360.

Lauterwein, M., Oethinger, M., Belsner, K., Peters, T., and Marre, R. (1995). In vitro activities of the lichen secondary metabolites vulpinic acid, (+)-usnic acid, and (-)-usnic acid against aerobic and anaerobic microorganisms. Antimicrob. Ag. Chem. 39, 2541-2543. doi: 10.1128/aac.39.11.2541

Lavallée, V. P. (2011). Antipain and its analogues, natural product inhibitors of Cathepsin $\mathrm{K}$ isolated from Streptomyces. doctoral dissertation, Vancouver (Canada): University of British Columbia.
Lawrey, J. D., and Diederich, P. (2003). Lichenicolous fungi: interactions, evolution, and biodiversity. Bryologist 106, 80-120. doi: 10.1639/00072745(2003)106[0080:Ifieab]2.0.co;2

Le Pogam, P., Legouin, B., Geairon, A., Rogniaux, H., Lohézic-Le Dévéhat, F., Obermayer, et al. (2016). Spatial mapping of lichen specialized metabolites using LDI-MSI: chemical ecology issues for Ophioparma ventosa. Sci. Rep. 6:1. doi: 10.1038/srep37807

Lee, Y. M., Kim, E. H., Lee, H. K., and Hong, S. G. (2014). Biodiversity and physiological characteristics of Antarctic and Arctic lichens-associated bacteria. World J. Microb. Biot. 30, 2711-2721. doi: 10.1007/s11274-014-1695-z

Leiman, S. A., May, J. M., Lebar, M. D., Kahne, D., Kolter, R., and Losick, R. (2013). D-amino acids indirectly inhibit biofilm formation in Bacillus subtilis by interfering with protein synthesis. J. Bacteriol. 195, 5391-5395. doi: 10.1128/jb. 00975-13

Leiva, D., Fernández-Mendoza, F., Acevedo, J., Carú, M., Grube, M., and Orlando, J. (2021). The Bacterial community of the foliose macro-lichen Peltigera frigida is more than a mere extension of the microbiota of the subjacent substrate. Microb. Ecol. 1:12. doi: 10.1007/s00248-020-01662-y

Lenova, L. I., and Blum, O. (1983). To the question on the third component of lichens. Bot. J. 68, 21-28.

Leveau, J. H. J., and Preston, G. M. (2008). Bacterial mycophagy: definition and diagnosis of a unique bacterial-fungal interaction. N. Phytol. 177, 859-876. doi: 10.1111/j.1469-8137.2007.02325.x

Levsky, J. M., and Singer, R. H. (2003). Fluorescence in situ hybridization: past, present and future. J. Cell Sci. 116, 2833-2838. doi: 10.1242/jcs.00633

Liba, C. M., Ferrara, F. I. S., Manfio, G. P., Fantinatti-Garboggini, F., Albuquerque, R. C., Pavan, C., et al. (2006). Nitrogen-fixing chemo-organotrophic bacteria isolated from cyanobacteria-deprived lichens and their ability to solubilize phosphate and to release amino acids and phytohormones. J. Appl. Microbiol. 101, 1076-1086. doi: 10.1111/j.1365-2672.2006.03010.x

Lines, C. E. M., Ratcliffe, R. G., Rees, T. A. V., and Southon, T. E. (1989). A ${ }^{13} \mathrm{C}$ NMR study of photosynthate transport and metabolism in the lichen Xanthoria calcicola Oxner. N. Phytol. 111, 447-456. doi: 10.1111/j.1469-8137. 1989.tb00707.x

Lisewski, V., and Ellis, C. J. (2010). Epiphyte sensitivity to a cross-scale interaction between habitat quality and macroclimate: an opportunity for range-edge conservation. Biodiv. Conserv. 19, 3935-3949. doi: 10.1007/s10531-010-9938-2

Liu, J., Prindle, A., Humphries, J., Gabalda-Sagarra, M., Asally, M., Dong-yeon, D. L., et al. (2015). Metabolic co-dependence gives rise to collective oscillations within biofilms. Nature 523, 550-554. doi: 10.1038/nature14660

Lumbsch, H. T., Ahti, T., Altermann, S., Paz, A. D. G., Aptroot, A., Arup, U., et al. (2011). One hundred new species of lichenized fungi: a signature of undiscovered global diversity. Phytotaxa 18, 1-127.

MacFarlane, J. D., and Kershaw, K. A. (1985). "Some aspects of carbohydrate metabolism in lichens," in Lichen Physiology and Cell Biology, ed. D. H. Brown (Boston, MA: Springer), 1-8. doi: 10.1007/978-1-4613-2527-7_1

Madeo, F., Eisenberg, T., Büttner, S., Ruckenstuhl, C., and Kroemer, G. (2010). Spermidine: A novel autophagy inducer and longevity elixir. Autophagy 6, 160-162. doi: 10.4161/auto.6.1.10600

Madeo, F., Eisenberg, T., Pietrocola, F., and Kroemer, G. (2018). Spermidine in health and disease. Science 359:6374. doi: 10.1126/science.aan2788

Mafole, T. C., Chiang, C., Solhaug, K. A., and Beckett, R. P. (2017). Melanisation in the old forest lichen Lobaria pulmonaria reduces the efficiency of photosynthesis. Fung. Ecol. 29, 103-110. doi: 10.1016/j.funeco.2017.07.004

Maguire, F., Jia, B., Gray, K. L., Lau, W. Y. V., Beiko, R. G., and Brinkman, F. S. (2020). Metagenome-assembled genome binning methods with short reads disproportionately fail for plasmids and genomic islands. Microb. Genomics 6:10. doi: $10.1099 /$ mgen. 0.000436

Maier, S., Schmidt, T. S., Zheng, L., Peer, T., Wagner, V., and Grube, M. (2014). Analyses of dryland biological soil crusts highlight lichens as an important regulator of microbial communities. Biodiv. Conserv. 23, 1735-1755. doi: 10. 1007/s10531-014-0719-1

Mark, K., Laanisto, L., Bueno, C. G., Niinemets, Ü, Keller, C., and Scheidegger, C. (2020). Contrasting co-occurrence patterns of photobiont and cystobasidiomycete yeast associated with common epiphytic lichen species. N. Phytol. 2020:16475. doi: 10.1111/nph.16475

Martínez, I., Flores, T., Otálora, M. A., Belinchón, R., Prieto, M., Aragón, G., et al. (2012). Multiple-scale environmental modulation of lichen reproduction. Fung. Biol. 116, 1192-1201. doi: 10.1016/j.funbio.2012.09.005 
Martinez, L. R., and Casadevall, A. (2015). Biofilm formation by Cryptococcus neoformans. Microbiol. Spectr. 3:3. doi: 10.1128/9781555817466.ch7

Matee, L. P., Beckett, R. P., Solhaug, K. A., and Minibayeva, F. V. (2016). Characterization and role of tyrosinases in the lichen Lobaria pulmonaria (L.) Hoffm. Lichenologist 48, 311-322. doi: 10.1017/s0024282916000293

McEvoy, M., Gauslaa, Y., and Solhaug, K. A. (2007). Changes in pools of depsidones and melanins, and their function, during growth and acclimation under contrasting natural light in the lichen Lobaria pulmonaria. N. Phytol. 175, 271-282. doi: 10.1111/j.1469-8137.2007.02096.x

McGinnis, M. W., Parker, Z. M., Walter, N. E., Rutkovsky, A. C., Cartaya-Marin, C., and Karatan, E. (2009). Spermidine regulates Vibrio cholera biofilm formation via transport and signaling pathways. FEMS Microbiol. Lett. 299, 166-174. doi: $10.1111 / j .1574-6968.2009 .01744 . x$

Mechan Llontop, M. E. (2020). Identification, characterization, and use of precipitation-borne and plant-associated bacteria. Dissertation, Blacksburg (VA): Virginia Polytechnic Institute and State University.

Millanes, A. M., Diederich, P., and Wedin, M. (2016). Cyphobasidium gen. nov., a new lichen-inhabiting lineage in the Cystobasidiomycetes (Pucciniomycotina. Basidiomycota, Fungi). Fung. Biol. 120, 1468-1477. doi: 10.1016/j.funbio.2015. 12.003

Millbank, J. W., and Kershaw, K. A. (1970). Nitrogen metabolism in lichens. N. Phytol. 69, 595-597. doi: 10.1111/j.1469-8137.1970.tb07611.x

Minibayeva, F., and Beckett, R. P. (2001). High rates of extracellular superoxide production in bryophytes and lichens, and an oxidative burst in response to rehydration following desiccation. N. Phytol. 152, 333-341. doi: 10.1046/j. 0028-646x.2001.00256.x

Motohashi, K., Takagi, M., Yamamura, H., Hayakawa, M., and Shin-Ya, K. (2010). A new angucycline and a new butenolide isolated from lichen-derived Streptomyces sp. J. Antibiot. 63, 545-548. doi: 10.1038/ja.2010.94

Muggia, L., and Grube, M. (2018). Fungal diversity in lichens: from extremotolerance to interactions with algae. Life 8:15. doi: 10.3390/life8020015

Muggia, L., Klug, B., Berg, G., and Grube, M. (2013). Localization of bacteria in lichens from Alpine soil crusts by fluorescence in situ hybridization. Appl. Soil Ecol. 68, 20-25. doi: 10.1016/j.apsoil.2013.03.008

Mushegian, A. A., Peterson, C. N., Baker, C. C., and Pringle, A. (2011). Bacterial diversity across individual lichens. Appl. Environ. Microbiol. 77, 4249-4252. doi: 10.1128/aem.02850-10

Myllys, L., Stenroos, S., Thell, A., and Kuusinen, M. (2007). High cyanobiont selectivity of epiphytic lichens in old growth boreal forest of Finland. N. Phytol. 173, 621-629. doi: 10.1111/j.1469-8137.2006.01944.x

Narasingarao, P., Podell, S., Ugalde, J. A., Brochier-Armanet, C., Emerson, J. B., Brocks, J. J., et al. (2012). De novo metagenomic assembly reveals abundant novel major lineage of Archaea in hypersaline microbial communities. ISME J. 6, 81-93. doi: 10.1038/ismej.2011.78

Nash, T. H. III (2008). "Nitrogen, its metabolism and potential contribution to ecosystems," in Lichen biology, 2nd Edn, ed. T. H. Nash III (Cambridge: Cambridge University Press), 216-233. doi: 10.1017/cbo9780511790478.012

Nash, T. H. III (ed.) (1996). Lichen biology. Cambridge: Cambridge University Press.

Nelson, P. E. (1992). Taxonomy and biology of Fusarium moniliforme. Mycopathol. 117, 29-36. doi: 10.1007/bf00497276

Noh, H. J., Lee, Y. M., Park, C. H., Lee, H. K., Cho, J. C., and Hong, S. G. (2020). Microbiome in Cladonia squamosa is vertically stratified according to microclimatic conditions. Front. Microbiol. 11:268. doi: 10.3389/fmicb.2020. 00268

Nowotarski, S. L., Woster, P. M., and Casero, Jr. (2013). Polyamines and cancer: implications for chemotherapy and chemoprevention. Exp. Rev. Molec. Med. 15:3. doi: $10.1017 /$ erm.2013.3

Nybakken, L., Asplund, J., Solhaug, K. A., and Gauslaa, Y. (2007). Forest successional stage affects the cortical secondary chemistry of three old forest lichens. J. Chem. Ecol. 33, 1607-1618. doi: 10.1007/s10886-007-9339-5

Öckinger, E., Niklasson, M., and Nilsson, S. G. (2005). Is local distribution of the epiphytic lichen Lobaria pulmonaria limited by dispersal capacity or habitat quality? Biodiv. Conserv. 14, 759-773. doi: 10.1007/s10531-004-4535-x

Oksanen, I., Jokela, J., Fewer, D. P., Wahlsten, M., Rikkinen, J., and Sivonen, K. (2004). Discovery of rare and highly toxic microcystins from lichen-associated cyanobacterium Nostoc sp. strain IO-102-I. Appl. Environ. Microbiol. 70, 57565763. doi: 10.1128/aem.70.10.5756-5763.2004
Olafsdottir, E. S., and Ingólfsdottir, K. (2001). Polysaccharides from lichens: structural characteristics and biological activity. Planta Med. 67, 199-208. doi: $10.1055 / \mathrm{s}-2001-12012$

Palmqvist, K. (2002). "Cyanolichens: carbon metabolism," in Cyanobacteria in symbiosis, eds A. N. Rai, B. Bergman, and U. Rasmussen (Berlin: SpringerVerlag), 73-96. doi: 10.1007/0-306-48005-0_5

Pande, S., Merker, H., Bohl, K., Reichelt, M., Schuster, S., De Figueiredo, L. F., et al. (2014). Fitness and stability of obligate cross-feeding interactions that emerge upon gene loss in bacteria. ISME J. 8, 953-962. doi: 10.1038/ismej.20 13.211

Pankratov, T. A. (2012). Acidobacteria in microbial communities of the bog and tundra lichens. Microbiol. 81, 51-58. doi: 10.1134/s0026261711060166

Pankratov, T. A., and Dedysh, S. N. (2010). Granulicella paludicola gen. nov., sp. nov., Granulicella pectinivorans sp. nov., Granulicella aggregans sp. nov. and Granulicella rosea sp. nov., acidophilic, polymer-degrading acidobacteria from Sphagnum peat bogs. Int. J. Syst. Evol. Microbiol. 60, 2951-2959. doi: 10.1099/ijs.0.021824-0

Pankratov, T. A., Grouzdev, D. S., Patutina, E. O., Kolganova, T. V., Suzina, N. E., and Berestovskaya, J. J. (2019). Lichenibacterium ramalinae gen. nov, sp. nov., Lichenibacterium minor sp. nov., the first endophytic, beta-carotene producing bacterial representatives from lichen thalli and the proposal of the new family Lichenibacteriaceae within the order Rhizobiales. Antonie van Leeuwenhoek 113, 477-489. doi: 10.1007/s10482-019-01357-6

Panosyan, A. K., and Nikogosyan, V. G. (1966). The presence of Azotobacter in lichens. Akad. Nauk. Armenian SSR, Biol. Zhurn. Armen. 19, 3-11.

Parks, D. H., Rinke, C., Chuvochina, M., Chaumeil, P. A., Woodcroft, B. J., Evans, P. N., et al. (2017). Recovery of nearly 8,000 metagenome-assembled genomes substantially expands the tree of life. Nat. Microbiol. 2, 1533-1542. doi: 10.1038/s41564-017-0012-7

Parrot, D., Antony-Babu, S., Intertaglia, L., Grube, M., Tomasi, S., and Suzuki, M. T. (2015). Littoral lichens as a novel source of potentially bioactive Actinobacteria. Sci. Rep. 5:15839. doi: 10.1038/srep15839

Parrot, D., Legrave, N., Delmail, D., Grube, M., Suzuki, M. T., and Tomasi, S. (2016). Review - lichen-associated bacteria as a hot spot of chemodiversity: focus on uncialamycin, a promising compound for future medicinal applications. Planta Med. 82, 1143-1152. doi: 10.1055/s-0042-105571

Partida-Martinez, L. P., Monajembashi, S., Greulich, K. O., and Hertweck, C. (2007). Endosymbiont-dependent host reproduction maintains bacterial-fungal mutualism. Curr. Biol. 17, 773-777. doi: 10.1016/j.cub.2007.03.039

Paungfoo-Lonhienne, C., Rentsch, D., Robatzek, S., Webb, R. I., Sagulenko, E., Näsholm, T., et al. (2010). Turning the table: plants consume microbes as a source of nutrients. PLoS One 5:7. doi: 10.1371/journal.pone.0011915

Petrzik, K., Koloniuk, I., Sarkisová, T., and Éíhal, L. (2016). Detection of herbaceous-plant pararetrovirus in lichen herbarium samples. Acta Virol. 60, 196-200. doi: 10.4149/av_2016_02_196

Petrzik, K., Koloniuk, I., Sehadová, H., and Sarkisova, T. (2019). Chrysoviruses inhabited symbiotic fungi of lichens. Viruses 11:12. doi: 10.3390/v11121120

Petrzik, K., Vondrák, J., Barták, M., Peksa, O., and Kubešová, O. (2014). Lichensa new source or yet unknown host of herbaceous plant viruses? Eur. J. Plant Pathol. 138, 549-559. doi: 10.1007/s10658-013-0246-z

Petrzik, K., Vondrák, J., Kvíderová, J., and Lukavsk $\iota$, J. (2015). Platinum anniversary: virus and lichen alga together more than 70 years. PloS One 10:3. doi: 10.1371/journal.pone. 0120768

Phillips, H. C. (1969). Annual growth rates of three species of foliose lichens determined photographically. Bull. Torrey Bot. Club 96, 202-206. doi: 10.2307/ 2483333

Piovano, M., Garbarino, J. A., Giannini, F. A., Correche, E. R., Feresin, G., Tapia, A., et al. (2002). Evaluation of antifungal and antibacterial activities of aromatic metabolites from lichens. Bol. Soc. Chi. Química 47, 235-240.

Poelt, J. (1990). Parasitische Arten der Flechtengattung Rhizocarpon - eine weitere Übersicht. Mitt. Bot. Staatssamml. München 29, 515-538.

Printzen, C., Fernández-Mendoza, F., Muggia, L., Berg, G., and Grube, M. (2012). Alphaproteobacterial communities in geographically distant populations of the lichen Cetraria aculeata. FEMS Microbiol. Ecol. 82, 316-325. doi: 10.1111/j. 1574-6941.2012.01358.x

Pucciarelli, S., Moreschini, B., Micozzi, D., De Fronzo, G. S., Carpi, F. M., Polzonetti, V., et al. (2012). Spermidine and spermine are enriched in whole blood of nona/centenarians. Rejuv. Res. 15, 590-595. doi: 10.1089/rej.2012.1349 
Purvis, O. W. (2014). Adaptation and interaction of saxicolous crustose lichens with metals. Bot. Stud. 55, 1-14.

Randlane, T., Jüriado, I., Suija, A., Lõhmus, P., and Leppik, E. (2008). Lichens in the new red data list of Estonia. Fol. Cryptog. Estonica 44, 113-120.

Richardson, D. H. S. (2002). Reflections on lichenology: achievements over the last 40 years and challenges for the future. Canad. J. Bot. 80, 101-113. doi: 10.1139/b02-011

Richardson, D. H. S., Hill, D. J., and Smith, D. C. (1968). Lichen physiology: XI. The role of the alga in determining the pattern of carbohydrate movement between lichen symbionts. N. Phytol. 67, 469-486. doi: 10.1111/j.1469-8137. 1968.tb05476.x

Romero-Olivares, A. L., Allison, S. D., and Treseder, K. K. (2017). Soil microbes and their response to experimental warming over time: a meta-analysis of field studies. Soil Biol. Biochem. 107, 32-40. doi: 10.1016/j.soilbio.2016.12.026

Rose, F. (1992). "Temperate forest management: its effect on bryophyte and lichen floras and habitats," in Bryophytes and lichens in a changing environment, eds J. W. Bates and A. M. Farmer (Oxford: Clarendon Press), 211-233.

Ruthes, A. C., Komura, D. L., Carbonero, E. R., Sassaki, G. L., Gorin, P. A., and Iacomini, M. (2010). Structural characterization of the uncommon polysaccharides obtained from Peltigera canina photobiont Nostoc muscorum. Carbohydr. Polym. 81, 29-34. doi: 10.1016/j.carbpol.2010.01.050

Saleem, M. (2015). "Microbiome ecosystem ecology: unseen majority in an anthropogenic ecosystem," in Microbiome Community Ecology, ed. S. Muhammad (Cham: Springer), 1-11. doi: 10.1007/978-3-319-11665-5_1

Saleh, A. M., Wilding, K. M., Calve, S., Bundy, B. C., and Kinzer-Ursem, T. L. (2019). Non-canonical amino acid labeling in proteomics and biotechnology. J. Med. Biol. Eng. 13:43. doi: 10.1186/s13036-019-0166-3

Sangwan, N., Xia, F., and Gilbert, J. A. (2016). Recovering complete and draft population genomes from metagenome datasets. Microbiome 4:8. doi: 10.1186/ s40168-016-0154-5

Scalabrino, G., and Ferioli, M. E. (1984). Polyamines in mammalian ageing: an oncological problem, too? A Rev. Mech. Ageing Dev. 26, 149-164. doi: 10.1016/ 0047-6374(84)90090-3

Scheidegger, C. (1994). Low-temperature scanning electron microscopy: the localization of free and perturbed water and its role in the morphology of the lichen symbionts. Cryptog. Bot. 4, 290-290.

Scheidegger, C. (1995). Early development of transplanted Isidioid soredia of Lobaria pulmonaria in an endangered population. Lichenologist 27, 361-374. doi: $10.1017 / \mathrm{s} 0024282995000478$

Scheidegger, C., and Clerc, P. (2002). Rote Liste der gefährdeten Arten der Schweiz: Baum- und erdbewohnende Flechten. Bundesamt für Umwelt, Wald und Landschaft BUWAL, Bern, und Eidgenössische Forschungsanstalt WSL, Birmensdorf, und Conservatoire et Jardin botaniques de la Ville de Genève CJBG. BUWAL-Reihe Vollzug Umwelt 2002:124.

Scheidegger, C., and Goward, T. (2002). "“'Monitoring lichens for conservation: red lists and conservation action plans,"," in Monitoring with Lichens - Monitoring Lichens, eds P. L. Nimis, C. Scheidegger, and P. A. Wolseley (Berlin: Springer, Kluwer Academic Publisher), 163-181. doi: 10.1007/978-94-010-0423-7_12

Scheidegger, C., Frey, B., and Walser, J. C. (1998). "Reintroduction and augmentation of populations of the endangered Lobaria pulmonaria: methods and concepts," in Lobarion Lichens as Indicators of Primeval Forests of Eastern Carpathians, eds S. Kondratyuk and B. Coppins. Kostrino: Darwin International Workshop, 33-52.

Scherrer, S., De Vries, O. M., Dudler, R., Wessels, J. G., and Honegger, R. (2000). Interfacial self-assembly of fungal hydrophobins of the lichen-forming ascomycetes Xanthoria parietina and X. ectaneoides. Fung. Genet. Biol. 30, 81-93. doi: 10.1006/fgbi.2000.1205

Schiebenhoefer, H., Van Den Bossche, T., Fuchs, S., Renard, B. Y., Muth, T., and Martens, L. (2019). Challenges and promise at the interface of metaproteomics and genomics: an overview of recent progress in metaproteogenomic data analysis. Expert Rev. Proteomics 16, 375-390. doi: 10.1080/14789450.2019. 1609944

Schiefelbein, U., and Thell, A. (2018). Current state of Lobaria pulmonaria in southernmost Sweden. Graphis Scripta 30, 94-104.

Schneider, T., Schmid, E., de Castro, Jr., Cardinale, M., Eberl, L., Grube, M., et al. (2011). Structure and function of the symbiosis partners of the lung lichen (Lobaria pulmonaria L. Hoffm.) analyzed by metaproteomics. Proteomics 11, 2752-2756. doi: 10.1002/pmic.201000679
Seaward, M. R. D. (1998). Lichen Atlas of the British Isles: Fascicle 3: The Foliose Physciaceae (Anaptychia, Heterodermia, Hyperphyscia, Phaeophyscia, Physcia, Physconia, Tornabea), Arctomia, Lobaria, Massalongia, Pseudocyphellaria, Psoroma, Solorina, Sticta, Teloschistes. London: British Lichen Society.

Seifert, J., Taubert, M., Jehmlich, N., Schmidt, F., Völker, U., Vogt, C., et al. (2012). Protein-based stable isotope probing (protein-SIP) in functional metaproteomics. Mass Spectr. Rev. 31, 683-697. doi: 10.1002/mas.21346

Selbmann, L., Zucconi, L., Ruisi, S., Grube, M., Cardinale, M., and Onofri, S. (2010). Culturable bacteria associated with Antarctic lichens: affiliation and psychrotolerance. Polar Biol. 33, 71-83. doi: 10.1007/s00300-009-0686-2

Shrestha, G., and Clair, L. L. (2013). Lichens: a promising source of antibiotic and anticancer drugs. Phytochem. Rev. 12, 229-244. doi: 10.1007/s11101-0139283-7

Sigurbjörnsdóttir, M. A., Heiðmarsson, S., Jónsdóttir, A. R., and Vilhelmsson, O. (2014). Novel bacteria associated with Arctic seashore lichens have potential roles in nutrient scavenging. Can. J. Microbiol. 60, 307-317. doi: 10.1139/cjm2013-0888

Singh, S. B., Garrity, G. M., Genillourd, O., Lingham, R. B., Martin, I., NallinOmstead, M., et al. (1997). Inhibitor compounds of farnesyl-protein transferase and chemotherapeutic compositions containing the same, produced by strain ATCC 55532. U.S. Patent No. 5,627,057. Washington, DC: U.S. Patent and Trademark Office.

Smith, C. W., Aptroot, A., Coppins, B. J., Fletcher, A., Gilbert, O. L., James, P. W., et al. (2009). The lichens of Great Britain and Ireland. London: British Lichen Society.

Smith, D. C. (1980). "Mechanisms of nutrient movement between the lichen symbionts," in Cellular Interactions in Symbiosis and Parasitism, eds C. B. Cook, P. W. Pappas, and E. D. Rudolph (Ohio: Ohio State University Press), 197-227.

Smith, D. C., and Douglas, A. E. (1987). The biology of symbiosis. London: Edward Arnold Publishers.

Snäll, T., Ribeiro, Jr., and Rydin, H. (2003). Spatial occurrence and colonisations in patch-tracking metapopulations: local conditions versus dispersal. Oikos 103, 566-578. doi: 10.1034/j.1600-0706.2003.12551.x

Soda, K., Kano, Y., and Chiba, F. (2012). Food polyamine and cardiovascular disease- an epidemiological study. Glob. J. Health Sci. 4, 170-178.

Solhaug, K. A., Gauslaa, Y., Nybakken, L., and Bilger, W. (2003). UV-induction of sun-screening pigments in lichens. N. Phytol. 158, 91-100. doi: 10.1046/j.14698137.2003.00708.x

Solhaug, K. A., Larsson, P., and Gauslaa, Y. (2010). Light screening in lichen cortices can be quantified by chlorophyll fluorescence techniques for both reflecting and absorbing pigments. Planta 231, 1003-1011. doi: 10.1007/ s00425-010-1103-3

Spribille, T. (2018). Relative symbiont input and the lichen symbiotic outcome. Curr. Op. Pl. Biol. 44, 57-63. doi: 10.1016/j.pbi.2018.02.007

Spribille, T., Tagirdzhanova, G., Goyette, S., Tuovinen, V., Case, R., and Zandberg, W. F. (2020). 3D biofilms: in search of the polysaccharides holding together lichen symbioses. FEMS Microbiol. Lett. 367:5. doi: 10.1093/femsle/fnaa023

Spribille, T., Tuovinen, V., Resl, P., Vanderpool, D., Wolinski, H., Aime, M. C., et al. (2016). Basidiomycete yeasts in the cortex of ascomycete macrolichens. Science $353,488-492$. doi: $10.1126 /$ science.aaf 8287

Stenroos, S., Stocker-Wörgötter, E., Yoshimura, I., Myllys, L., Thell, A., and Hyvönen, J. (2003). Culture experiments and DNA sequence data confirm the identity of Lobaria photomorphs. Canad. J. Bot. 81, 232-247. doi: 10.1139/b03027

Stewart, P. S., and Franklin, M. J. (2008). Physiological heterogeneity in biofilms. Nat. Rev. Microbiol. 6, 199-210. doi: 10.1038/nrmicro1838

Sundberg, B., Lundberg, P., Ekblad, A., and Palmqvist, K. (1999). "In vivo ${ }^{13}$ C NMR spectroscopy of carbon fluxes in four diverse lichens," in Physiological ecology of lichen growth, B. Sundberg, Paper VI. Umea (Sweden): Umea University. dissertation.

Tuovinen, V., Ekman, S., Thor, G., Vanderpool, D., Spribille, T., and Johannesson, H. (2019). Two basidiomycete fungi in the cortex of wolf lichens. Curr. Biol. 29, 476-483. doi: 10.1016/j.cub.2018.12.022

Türk, R., and Hafellner, J. (1999). "Rote Liste gefährdeter Flechten (Lichenes) Österreichs," in Rote Listen gefährdeter Pflanzen Österreichs. - Grüne Reihe des Bundesministeriums für Umwelt, Jugend und Familie, 2. Fassung, ed. H. Niklfeld (Graz: Austria Medien Service), 187-228. doi: 10.1007/978-3-642-49916-6_8

Ullah, J., Khanum, Z., Khan, I. A., Khalid, A. N., Musharraf, S. G., and Ali, A. (2020). Metaproteomics reveals the structural and functional diversity of 
Dermatocarpon miniatum (L.) W. Mann. Microbiota. Fung. Biol. 125, 32-38. doi: 10.1016/j.funbio.2020.10.001

Urayama, S. I., Kondo, F., Chiba, Y., Takaki, Y., Hirai, M., Minegishi, Y., et al. (2020). Diverged and active partitiviruses in lichen. Front. Microbiol. 11:2576.

Von Bergen, M., Jehmlich, N., Taubert, M., Vogt, C., Bastida, F., Herbst, F. A., et al. (2013). Insights from quantitative metaproteomics and protein-stable isotope probing into microbial ecology. ISME J. 7, 1877-1885. doi: 10.1038/ismej.20 13.78

Walch, A., Rauser, S., Deininger, S. O., and Höfler, H. (2008). MALDI imaging mass spectrometry for direct tissue analysis: a new frontier for molecular histology. Histochem. Cell Biol. 130, 421-434. doi: 10.1007/s00418-0080469-9

Walser, J. C. (2004). Molecular evidence for limited dispersal of vegetative propagules in the epiphytic lichen Lobaria pulmonaria. Am. J. Bot. 9, 12731276. doi: 10.3732/ajb.91.8.1273

Walser, J. C., Zoller, S., Büchler, U., and Scheidegger, C. (2001). Species-specific detection of Lobaria pulmonaria (lichenized ascomycete) diaspores in litter samples trapped in snow cover. Mol. Ecol. 10, 2129-2138. doi: 10.1046/j.1365294x.2001.01353.x

Wang, J.-T., and Douglas, A. E. (1997). Nutrients, signals, and photosynthate release by symbiotic algae (the impact of taurine on the dinoflagellate alga Symbiodinium from the sea anemone Aiptasia pulchella). Plant Physiol. 114, 631-636. doi: 10.1104/pp.114.2.631

Wedin, M., Maier, S., Fernandez-Brime, S., Cronholm, B., Westberg, M., and Grube, M. (2016). Microbiome change by symbiotic invasion in lichens. Environ. Microbiol. 18, 1428-1439. doi: 10.1111/1462-2920.13032

Werth, S., and Scheidegger, C. (2012). Congruent genetic structure in the lichenforming fungus Lobaria pulmonaria and its green-algal photobiont. Mol. Plant-Microbe Interact. 25, 220-230. doi: 10.1094/mpmi-03-11-0081

Werth, S., and Sork, V. L. (2010). Identity and genetic structure of the photobiont of the epiphytic lichen Ramalina menziesii on three oak species in southern California. Am. J. Bot. 97, 821-830. doi: 10.3732/ajb.0900276

Werth, S., Wagner, H. H., Gugerli, F., Holderegger, R., Csencsics, D., Kalwij, J. M., et al. (2006). Quantifying dispersal and establishment limitation in a population of an epiphytic lichen. Ecology 87, 2037-2046. doi: 10.1890/0012-9658(2006) 87[2037:qdaeli]2.0.co;2

West, N. J., Parrot, D., Fayet, C., Grube, M., Tomasi, S., and Suzuki, M. T. (2018). Marine cyanolichens from different littoral zones are associated with distinct bacterial communities. PeerJ. 6:5208. doi: 10.7717/peerj.5208
Wicaksono, W. A., Cernava, T., Grube, M., and Berg, G. (2020). Assembly of bacterial genomes from the metagenomes of three lichen species. Microbiol. Res. Announc. 9:38. doi: 10.1128/MRA.00622-20

Williams, D. E., Davies, J., Patrick, B. O., Bottriell, H., Tarling, T., Roberge, M., et al. (2008). Cladoniamides A-G tryptophan-derived alkaloids produced in Culture by Streptomyces uncialis. Org. Lett. 10, 3501-3504. doi: 10.1021/ol801 $274 \mathrm{c}$

Williamson, B., Tudzynski, B., Tudzynski, P., and Van Kan, J. A. (2007). Botrytis cinerea: the cause of grey mould disease. Mol. Plant Pathol. 8, 561-580. doi: 10.1111/j.1364-3703.2007.00417.x

Wirth, V. (1968). Soziologie, Standortsökologie und Areal des Lobarion pulmonariae im Südschwarzwald. Bot. Jahrbücher. 88, 317-305.

Wirth, V., Hauck, M., and Schultz, M. (2013). Die Flechten Deutschlands. Stuttgart: Eugen Ulmer KG, 2.

Wirth, V., Hauck, M., Brackel, W. V., Cezanne, R., De Bruyn, U., Dürhammer, O., et al. (2011). Rote Liste und Artenverzeichnis der Flechten und flechtenbewohnenden Pilze Deutschlands. Naturschutz und Biologische Vielfalt 70, 7-122.

Wolseley, P., and James, P. (2000). Factors affecting changes in species of Lobaria in sites across Britain. For. Snow Landsc. Res. 75, 319-338.

Wornik, S., and Grube, M. (2010). Joint dispersal does not imply maintenance of partnerships in lichen symbioses. Microb. Ecol. 59, 150-157. doi: 10.1007/ s00248-009-9584-y

Yasuda, Y., Kaleta, J., and Brömme, D. (2005). The role of cathepsins in osteoporosis and arthritis: rationale for the design of new therapeutics. $A d v$. Drug Deliv. Rev. 57, 973-993. doi: 10.1016/j.addr.2004.12.013

Conflict of Interest: The authors declare that the research was conducted in the absence of any commercial or financial relationships that could be construed as a potential conflict of interest.

Copyright (c) 2021 Grimm, Grube, Schiefelbein, Zühlke, Bernhardt and Riedel. This is an open-access article distributed under the terms of the Creative Commons Attribution License (CC BY). The use, distribution or reproduction in other forums is permitted, provided the original author(s) and the copyright owner(s) are credited and that the original publication in this journal is cited, in accordance with accepted academic practice. No use, distribution or reproduction is permitted which does not comply with these terms. 